Prepared in cooperation with U.S. Bureau of Reclamation

\title{
Using the Precipitation-Runoff Modeling System to Predict Seasonal Water Availability in the Upper Klamath River Basin, Oregon and California
}

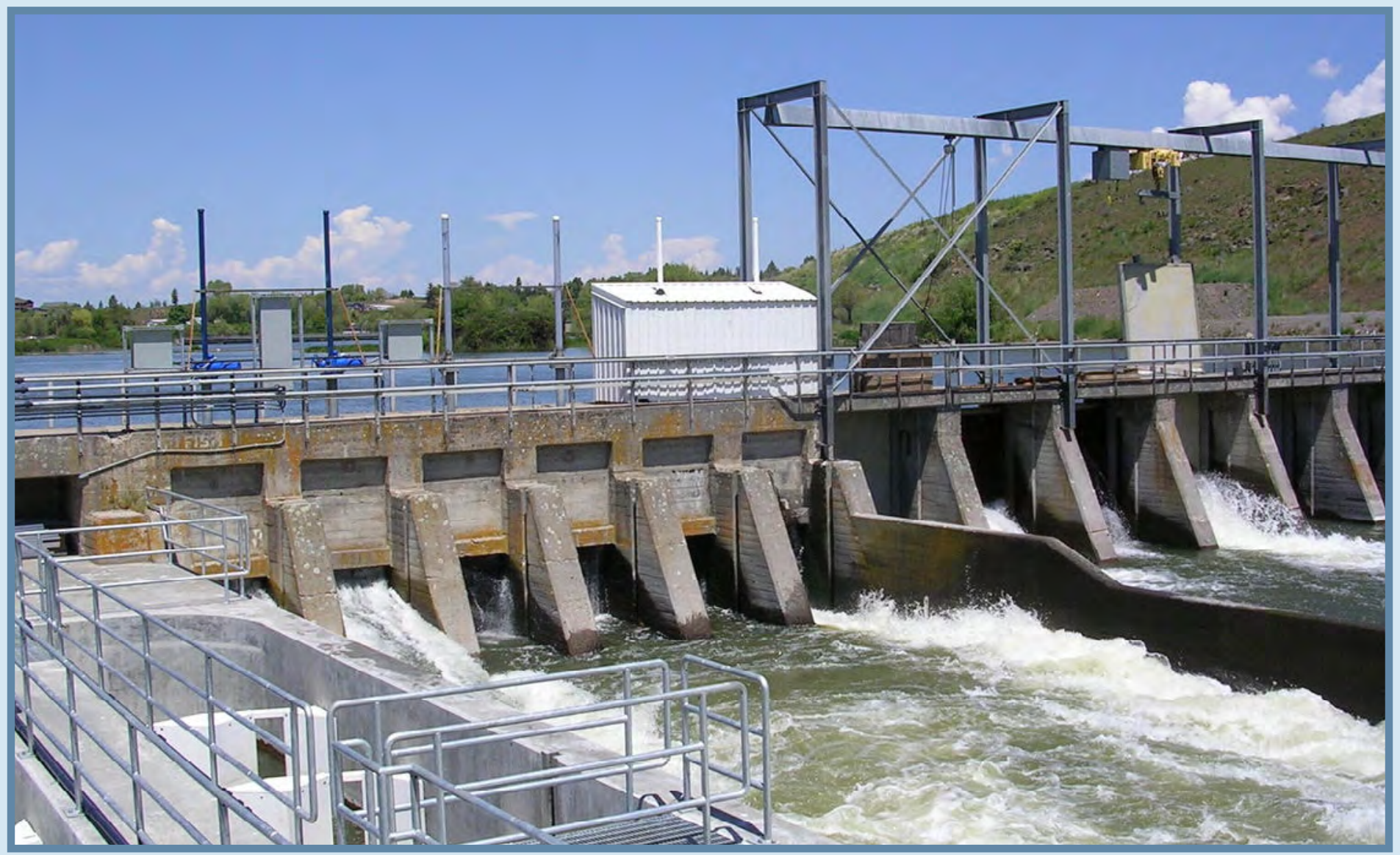

Scientific Investigations Report 2019-5044 
Cover: Photograph of Link River Dam, Klamath Falls, Oregon. Taken by John Risley, U.S.

Geological Survey, May 30, 2005. 


\section{Using the Precipitation-Runoff Modeling System to Predict Seasonal Water Availability in the Upper Klamath River Basin, Oregon and California}

By John C. Risley

Prepared in cooperation with the U.S. Bureau of Reclamation

Scientific Investigations Report 2019-5044 


\title{
U.S. Department of the Interior DAVID BERNHARDT, Secretary
}

\author{
U.S. Geological Survey \\ James F. Reilly II, Director
}

\section{U.S. Geological Survey, Reston, Virginia: 2019}

For more information on the USGS - the Federal source for science about the Earth, its natural and living resources, natural hazards, and the environment-visit https://www.usgs.gov or call 1-888-ASK-USGS.

For an overview of USGS information products, including maps, imagery, and publications, visit https://store.usgs.gov.

Any use of trade, firm, or product names is for descriptive purposes only and does not imply endorsement by the U.S. Government.

Although this information product, for the most part, is in the public domain, it also may contain copyrighted materials as noted in the text. Permission to reproduce copyrighted items must be secured from the copyright owner.

Suggested citation:

Risley, J.C., 2019, Using the precipitation-runoff modeling system to predict seasonal water availability in the upper Klamath River basin, Oregon and California: U.S. Geological Survey Scientific Investigations Report 2019-5044, 37 p., https://doi.org/10.3133/sir20195044.

ISSN 2328-0328 (online) 


\section{Contents}

Abstract

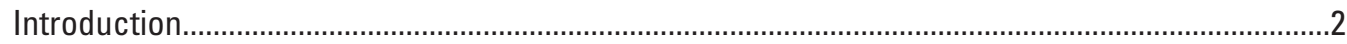

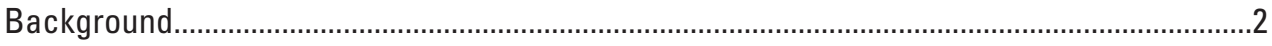

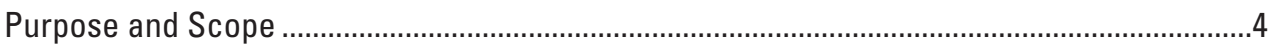

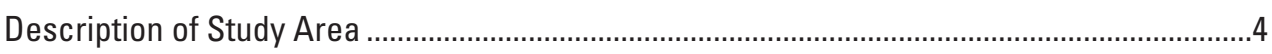

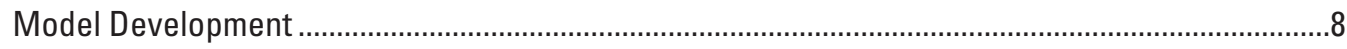

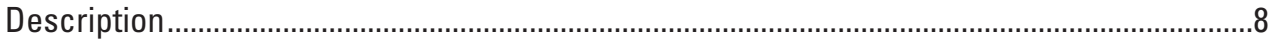

Delineation and Parameterization of Spatial Features............................................................

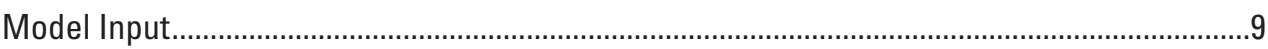

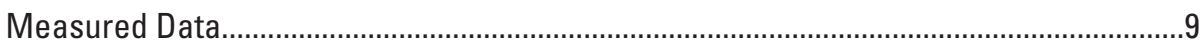

Data Distribution Methodology ....................................................................................

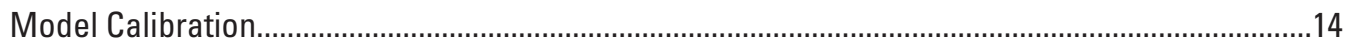

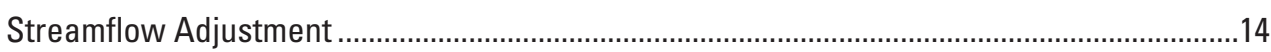

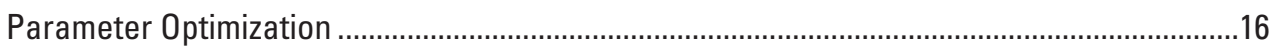

Shortwave Solar Radiation ........................................................................................16

Potential Evapotranspiration .......................................................................................17

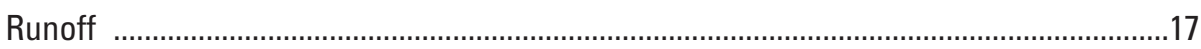

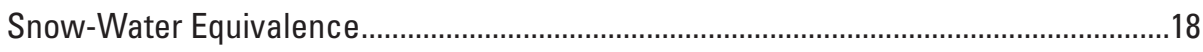

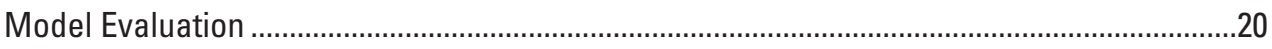

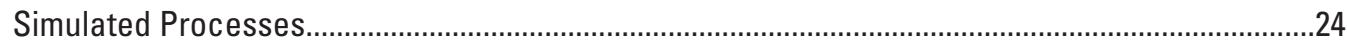

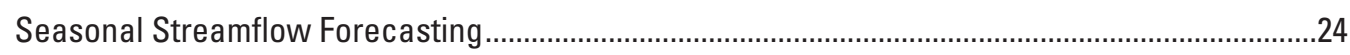

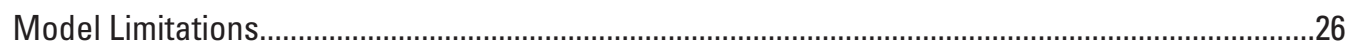

Summary

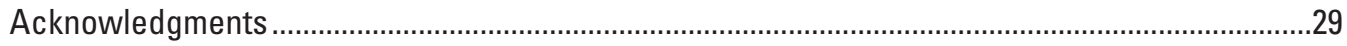

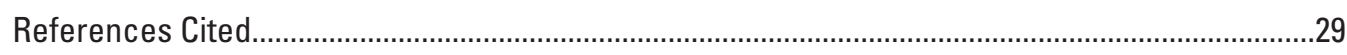

Appendix 1. Creating Climate Input Files for the Upper Klamath Basin

Precipitation-Runoff Modeling System Model ...............................................................33

Appendix 2. Running the Upper Klamath Basin Precipitation-Runoff Modeling System Model....35

Appendix 3. Real-Time Seasonal Forecasting with the Upper Klamath Basin

Precipitation-Runoff Modeling System Model .......................................................................36 


\section{Figures}

1. Map showing the Upper Klamath Basin, Oregon and California, and the Precipitation-Runoff Modeling System model domain.

2. Map showing mean annual precipitation in the Upper Klamath Basin, Oregon and California, 1981-2010.

3. Map showing geology in the Upper Klamath Basin, Oregon and California ......................6

4. Schematic diagram of the Precipitation-Runoff Modeling System .................................8

5. Map showing the Upper Klamath Basin model hydrologic response units ....................10

6. Map showing U.S. National Weather Service and Natural Resources Conservation Service meteorological stations.

7. Graph showing measured and simulated mean-monthly shortwave radiation for the Upper Klamath Lake basin, Oregon, water years 1981-2015.

8. Graph showing measured and simulated mean-monthly potential evapotranspiration for the Upper Klamath Lake basin, Oregon, water years 1981-2015

9. Graphs showing measured and simulated daily snow-water equivalence at eight snow telemetry stations in the upper Klamath River Basin, Oregon and California, water years 1986-2015....

10. Graph showing measured and simulated daily snow-water equivalence for the Upper Klamath Lake basin, Oregon, water years 2004-13

11. Graph showing adjusted measured and simulated daily streamflow at Sprague River near Chiloquin, Oregon (U.S. Geological Survey streamgage 11501000), for the calibration period, water years $2000-15$

12. Graph showing adjusted measured and simulated daily streamflow at Williamson River below Sprague River, near Chiloquin, Oregon (U.S. Geological Survey streamgage 11502500), for the calibration period, water years 2000-15

13. Graph showing constructed and simulated daily inflow to Upper Klamath Lake, Oregon, for the calibration period, water years 2000-15.

14. Graph showing adjusted measured and simulated mean-monthly streamflow at Sprague River near Chiloquin, Oregon (U.S. Geological Survey streamgage 11501000), water years 1984-2015.

16. Graph showing constructed and simulated mean-monthly inflow to Upper Klamath Lake, Oregon, water years 1984-2015.

15. Graph showing adjusted measured and simulated mean-monthly streamflow at Williamson River below Sprague River, near Chiloquin, Oregon (U.S. Geological Survey streamgage 11502500), water years 1984-2015

17. Graph showing mean-monthly simulated water-budget in the Upper Klamath Lake Basin, Oregon, water years 1984-2015.

19. Graph showing mean-monthly simulated rainfall and snowfall in the Upper Klamath Lake basin, Oregon, water years 1984-2015.

18. Graph showing mean-monthly simulated potential and actual evapotranspiration in the Upper Klamath Lake basin, Oregon, water years 1984-2015.

20. Graph showing mean-monthly simulated snow-water equivalence in the Upper Klamath Lake basin, Oregon, water years 1984 to 2015.

21. Graph showing Ensemble Streamflow Prediction (ESP) runs using water year 2015 simulated daily inflow to Upper Klamath Lake, Oregon . 


\section{Tables}

1. Streamgaging stations used for calibrating the Upper Klamath Basin

Precipitation-Runoff Modeling System models...

2. Precipitation Runoff Modeling System model parameter values determined from geospatial data.

3. U.S. National Weather Service and Natural Resources Conservation Service meteorological stations used in the model .......................................................................12

4. Streamflow adjustments for net consumptive use ..........................................................15

5. Precipitation Runoff Modeling System parameters and calibration steps using Let Us Calibrate (LUCA) for the Upper Klamath Basin model..

6. Percent bias, percent relative error, and root mean square error statistics for the three Precipitation-Runoff Modeling System models for the calibration period, water years $2000-15$.

7. Percent bias, percent relative error, and root mean square error statistics for the three Precipitation-Runoff Modeling System models for the validation period, water years 1984-99.

8. Adjusted measured and simulated mean-April-September streamflow for the three Precipitation-Runoff Modeling System models for water years 1984-2015..........23

9. Simulated inflow volumes to the Upper Klamath Lake for April-September 2015 using El Niño Southern Oscillation warm phase climate input data.....

\section{Conversion Factors}

U.S. customary units to International System of Units

\begin{tabular}{lcl}
\hline \multicolumn{1}{c}{ Multiply } & By & \multicolumn{1}{c}{ To obtain } \\
\hline inch (in.) & Length & \\
foot (ft) & 25.4 & millimeter $(\mathrm{mm})$ \\
mile (mi) & 0.3048 & meter $(\mathrm{m})$ \\
\hline & 1.609 & kilometer $(\mathrm{km})$ \\
\hline acre & Area & \\
square mile $\left(\mathrm{mi}^{2}\right)$ & 0.004047 & square kilometer $\left(\mathrm{km}^{2}\right)$ \\
\hline & 2.590 & square kilometer $\left(\mathrm{km}^{2}\right)$ \\
\hline cubic foot $\left(\mathrm{ft}^{3}\right)$ & Volume & \\
acre-foot $($ acre-ft) & 0.02832 & cubic meter $\left(\mathrm{m}^{3}\right)$ \\
acre-foot $($ acre-ft) & 1,233 & cubic meter $\left(\mathrm{m}^{3}\right)$ \\
\hline & 0.001233 & cubic hectometer $\left(\mathrm{hm}^{3}\right)$ \\
\hline cubic foot per second $\left(\mathrm{ft}^{3} / \mathrm{s}\right)$ & Flow rate & \\
\hline & 0.02832 & cubic meter per second $\left(\mathrm{m}^{3} / \mathrm{s}\right)$ \\
\hline langley (ly) & Shortwave radiation & \\
\hline
\end{tabular}

Temperature in degrees Fahrenheit $\left({ }^{\circ} \mathrm{F}\right)$ may be converted to degrees Celsius $\left({ }^{\circ} \mathrm{C}\right)$ as follows:

$$
{ }^{\circ} \mathrm{C}=\left({ }^{\circ} \mathrm{F}-32\right) / 1.8 .
$$




\section{Datums}

Vertical coordinate information is referenced to mean sea level, the North American Vertical Datum of 1988 (NAVD 88) or the National Geodetic Vertical Datum of 1929 (NGVD 29).

Horizontal coordinate information is referenced to the North American Datum of 1927 (NAD 27).

Elevation, as used in this report, refers to distance above the vertical datum.

\section{Supplemental Information}

The water year (WY) begins 0 ctober 1 and ends September 30 of the following year.

The WY is designated by the calendar year in which it ends; for example, WY 2014 begins on October 1, 2013, and ends on September 30, 2014. 


\title{
Using the Precipitation-Runoff Modeling System to Predict Seasonal Water Availability in the Upper Klamath River Basin, Oregon and California
}

\author{
By John C. Risley
}

\section{Abstract}

Accurate forecasts of the streamflow expected during late spring and summer in the Upper Klamath River Basin in southern-central Oregon and northern California are used by water management agencies to balance water allocations for agriculture, aquatic habitat, and hydropower-production needs. Streamflow forecasts are also used by irrigation farmers for planning. The forecasts are typically made twice a month starting as early in the water year as December. Multiple regression equations relating real-time snowpack and precipitation conditions to seasonal streamflow volumes have been used for many years in forecasting. However, with warming temperature trends and lower snowpack, such forecasts based on historical data could become less reliable in the future. If the timing and relation of snowpack and precipitation are outside of the range of the historical data used to create the equations, the forecasts become extrapolations. Statistical forecast equations are also limited in their ability to forecast streamflow in groundwater-dominated basins having inter-annual lag. As an additional method for seasonal streamflow forecasting, a physical-process-based hydrologic model employing the Precipitation-Runoff Modeling System (PRMS) was developed in cooperation with the U.S. Bureau of Reclamation for the Upper Klamath Basin in this study. The model was calibrated for the portion of the basin draining into Upper Klamath Lake. PRMS is a deterministic, distributed-parameter, physical-process-based modeling system developed by the U.S. Geological Survey. It simulates daily streamflow, snow, solar radiation, evapotranspiration, surface-water, and groundwater processes within the basin. A model calibration and validation period for water years 2000-15 and water years 1984-99, respectively, was used. The model was calibrated and validated using measured streamflow, snowpack, evapotranspiration, and solar radiation data sets. Interpolated daily precipitation and air temperature data from 32 meteorological stations within and surrounding the Upper Klamath Basin were used as model input. Performance statistics, used to evaluate how well simulated daily streamflow matched with measured streamflow included percent bias, percent relative error, and root-mean-square error. The statistics were computed annually, monthly, for October-March, and for April-September. With the exception of the October-March period, percent bias statistics were all within plus or minus 5-percent for both the calibration and validation periods. Limitations to using the model are error in the precipitation and air temperature input time series data, which include measurement error and error in the spatial interpolation method. Other errors include measured daily streamflow data, which were adjusted for consumptive use losses to make them more closely resemble natural streamflow for calibration.

The model developed for the Upper Klamath Basin can be used to forecast streamflow from the Sprague and Williamson River Basins and inflow to Upper Klamath Lake. Reliable forecasts at these locations are needed for managing water for irrigation, ecosystem health, and power production. Using the models in a forecast application requires assembling model input data sets of anticipated daily precipitation and minimum and maximum air temperature for the period after the date the forecast is made and the end of the forecasted period. These climate data sets can be based on historical or synthetic records, at the discretion of the forecaster. With the Ensemble Streamflow Prediction method, a suite of streamflow scenarios is simulated using multiple years of climate data as model input. The forecasted streamflow is determined from knowing the exceedance probabilities of the simulated streamflows. In this study, the model and the Ensemble Streamflow Prediction method were used to forecast the volume of inflow to Upper Klamath Lake for a 6-month period from April 1, 2015, to September 30, 2015, using a range of climate data sets based on El Niño Southern Oscillation (ENSO) criteria. Because 2015 was a warm phase ENSO period, climate data for 10 warm phase ENSO years from 1980 to 2010 were used as input to the model. The simulated April-September 2015 UKL inflow volume based on measured 2015 climate data was 482,000 acre-feet, which was very close to the 50th percent exceedance probability computed from 10 simulated scenarios that used warm phase ENSO climate input data from 1980-2010. 


\section{Introduction}

\section{Background}

The semiarid Upper Klamath River Basin (UKB) is in southern-central Oregon and northern California (fig. 1). For many decades, water management in the basin has relied on seasonal forecasts (provided by the United States Department of Agriculture's Natural Resources Conservation Service [NRCS] and the U.S. National Weather Service [NWS]), of streamflow entering the Upper Klamath Lake (UKL) and four other locations in the basin. The other locations include Clear Lake Reservoir, Gerber Reservoir, Williamson River below Sprague River near Chiloquin, Oregon, and Sprague River near Chiloquin. However, the forecast of total seasonal inflow to UKL is the most important forecast point for water managers because it involves a much greater volume of water than the other locations. Forecasts are posted twice a month by the NRCS from December to June and include a percentile range of streamflow volumes predicted over 4- or 6-month periods for the approaching spring and summer months such as March through July and April through September. Historically, the NRCS and NWS have forecasted seasonal streamflow volumes using a combination of multiple regression equations and real-time streamflow and climatological data analyses. Input variables to the regression equations for the UKB have typically included real-time monthly snowpack depths (measured as snow-water equivalence $[\mathrm{SWE}]$ ) and precipitation, both measured at locations in the same basin or vicinity of the forecast points. In addition to the NRCS regression equations, the United States Geological Survey (USGS) has also evaluated statistical methods for forecasting UKL inflow volumes (Risley and others, 2005). However, none of these methods, prior to this current study, used physical-process-based hydrologic models in seasonal streamflow forecasting.

Upper Klamath Lake is regulated by the Link River Dam, which is owned by the U.S. Bureau of Reclamation (BOR) and operated by the Pacific Power and Light Company (PacifiCorp) to provide water for agricultural, ecological habitat, and hydropower needs in the basin. During spring and summer, the BOR and other agencies must balance the amount of water that is: (1) passed through the Link River Dam, the outlet of the lake, for threatened Chinook (Oncorhynchus tshawytscha) and coho salmon (Oncorhynchus kisutch) in the lower Klamath River, (2) delivered from the lake, primarily through the A-Canal, to irrigate more than 200,000 acres (U.S. Bureau of Reclamation, 2018), (3) retained in UKL to maintain water quality and habitat for two endangered sucker species, (4) needed for the Lower Klamath and Tule Lake National Wildlife Refuges, and (5) hydroelectric power production. Although hydropower is no longer generated at Link River Dam, at the time of this study it is generated at dams located downstream of UKL.

Water for most of the irrigated land in the UKB, downstream of UKL, is supplied by the BOR. Established in 1905, the BOR Klamath Project (Project) includes reservoir regulation dams (Clear Lake and Gerber, in addition to UKL), a canal system, and approximately 240,000 acres of irrigable land (U.S. Bureau of Reclamation, 2018). Although the actual number of irrigated acres varies each year, the Project has generally provided water annually to 200,000 acres per year. Water delivered to most of the irrigated land in the Project comes from UKL.

In water year (WY) 2015, drought conditions occurred throughout most of Oregon and California (Oregon Water Resources Department, 2018). Almost all the NRCS Snow Telemetry (SNOTEL) sites in the UKB reported record-low SWE levels that year. However, total water-year precipitation for the drainage basin upstream of UKL was 25.6 inches (in.), which is greater than the median (24.8 in.) and less than the average (26.3 in.) for WYs 1981-2015 (PRISM Climate Group, 2018). If water year 2015 is a prelude of climate trends, the UKB could expect future years of less snowpack, increased rainfall, and a marked shift in the timing of runoff to earlier in the water year. However, statistical streamflow forecast equations must assume stationarity. Ideally, climate conditions during a year being forecasted should be within the historical range of the precipitation and SWE data used to create the equations. Physical-process-based based hydrologic models also assume climate stationarity because they are usually calibrated and validated using an historical streamflow time series. However, if they are calibrated on an historical period that includes extreme conditions, they can provide a more reliable and robust prediction of streamflow than a statistical regression model under climate conditions that are outside of the historical period of record (Rosenberg and others, 2011). A physical-process-based based hydrologic model also simulates water-budget and energy processes in a basin and can provide insights into complicated relations between snowpack, water supplies, weather, watershed conditions, and the influence of groundwater on streams. 


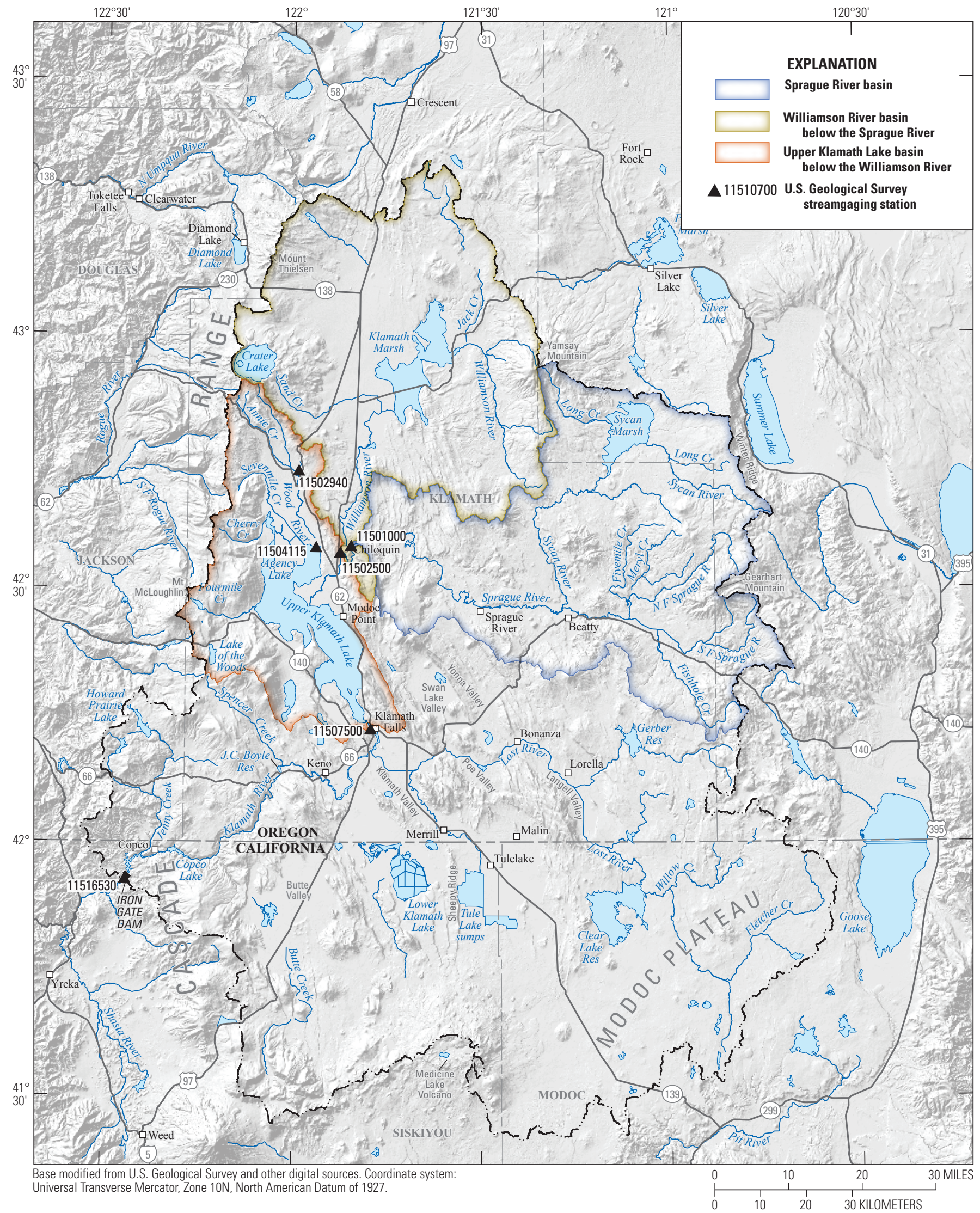

Figure 1. Upper Klamath Basin, Oregon and California, and the Precipitation-Runoff Modeling System model domain. Streamgaging stations shown on the map correspond to stations listed in table 1. 
To provide an additional method of seasonal streamflow forecasting in the Upper Klamath Basin, the USGS in cooperation with the BOR developed a physical-process-based hydrologic model. The model used in this study and described in this report is the USGS Precipitation-Runoff Modeling System (PRMS), version 5.0 (Markstrom and others, 2015; Regan and LaFontaine, 2017). PRMS is a deterministic, distributed-parameter, physical-process-based modeling system that can be used to simulate a suite of snow, solar radiation, evapotranspiration, surface-water, and groundwater processes on a daily time step.

Another challenge to using statistical equations in seasonal streamflow forecasting has been adequately capturing the more complicated surface-water and groundwater flow interactions that are much more dominant in the UKB than in many other NRCS forecast locations in the western United States. With greater groundwater storage, spring and summer streamflow in a given year can be vary depending on antecedent conditions of the previous 1 or 2 years. A year with an above-normal snowpack does not necessarily translate into above-average streamflow if it follows a drought period. Conversely, the effects of a drought in the current year might not be seen in streamflow if it follows a period of consecutive wet years. PRMS is able to simulate the multi-year lag in groundwater discharge that occurs in the UKB.

A possible future phase of this study will construct a fully coupled surface-water and groundwater model for the UKB using the USGS Ground-Water and Surface Water Flow (GSFLOW) model (Markstrom and others, 2008). GSFLOW couples both PRMS and the USGS Modular Ground-Water Flow Model (MODFLOW) (Harbaugh, 2005). Both PRMS and MODFLOW have been used in previous UKB studies for various applications (Risley and Hay, 2006; Hay and others, 2009; Gannett and others, 2012; Markstrom and others, 2012; and Risley and others, 2012). A fully developed GSFLOW model for the UKB could potentially be used for both seasonal streamflow forecasting and various water management applications that include groundwater pumping.

A physical-process-based based model should not necessarily be a replacement of statistical methods, such as multiple regression equations, in seasonal streamflow forecasting. There are advantages and disadvantages in using both methods.

\section{Purpose and Scope}

The objectives of the study include the following:

1. Construct a physical-process-based based watershed hydrologic model covering the UKB drainage basin;

2. Calibrate and validate the model for the portion of the UKB draining into UKL using measured streamflow, snowpack, evapotranspiration, and solar radiation data sets; and

3. Demonstrate the capability of the model for forecasting seasonal streamflow volumes using Ensemble Streamflow Prediction (ESP).

\section{Description of Study Area}

The study area and the model domain were the drainage area upstream of Iron Gate Dam, California, comprising approximately 8,300 square miles ( $\mathrm{mi}^{2}$; fig. 1$)$. The focus of the study was on simulating flows into Upper Klamath Lake in the northern part of the study and model area. The Klamath River originates near the outlet of UKL and flows 255 miles to the Pacific Ocean in northern California. Elevations in the UKB range from 2,162 feet (ft) at Iron Gate Dam to greater than 9,000 ft in the Oregon Cascade Range. The Williamson River Basin (including the Sprague River Basin) is approximately 3,000 $\mathrm{mi}^{2}$ in area. The Sprague River has a drainage area of approximately $1,580 \mathrm{mi}^{2}$ and drains part of the eastern side of Williamson River Basin. Together, the Williamson and Sprague Rivers encompass about 79 percent of the catchment above UKL and supply about one-half of the inflow. The other half of water entering the lake comes from the Wood River, creeks located mostly on the west side of the lake, springs and seeps in the lake, and precipitation. Surface outflow from the lake goes through the Link River Dam and the A Canal. Evapotranspiration accounts for approximately 16 percent of total water leaving the lake (Hubbard, 1970; Gannett and others, 2007).

Average annual precipitation (1981-2010) in the UKB ranges from approximately 11 to $12 \mathrm{in}$. in the Tule Lake region to 65 to $70 \mathrm{in}$. in the Cascade Range (PRISM Climate Group, 2018) (fig. 2). The Cascade Range creates a rain shadow that affects the areal distribution of precipitation throughout much of the UKB. Mean annual precipitation (1981-2010) in the upper Williamson River Basin (not including the Sprague River and upstream of the USGS Williamson River gage at Klamath Agency), the Sprague River Basin, and Wood River Basin is approximately 24,19 , and 23 in., respectively. For the entire drainage upstream of UKL, mean annual precipitation is approximately $22 \mathrm{in.} \mathrm{More} \mathrm{than} \mathrm{half} \mathrm{of} \mathrm{annual} \mathrm{precipitation}$ (1981-2010) occurs November-February (PRISM Climate Group, 2018). 


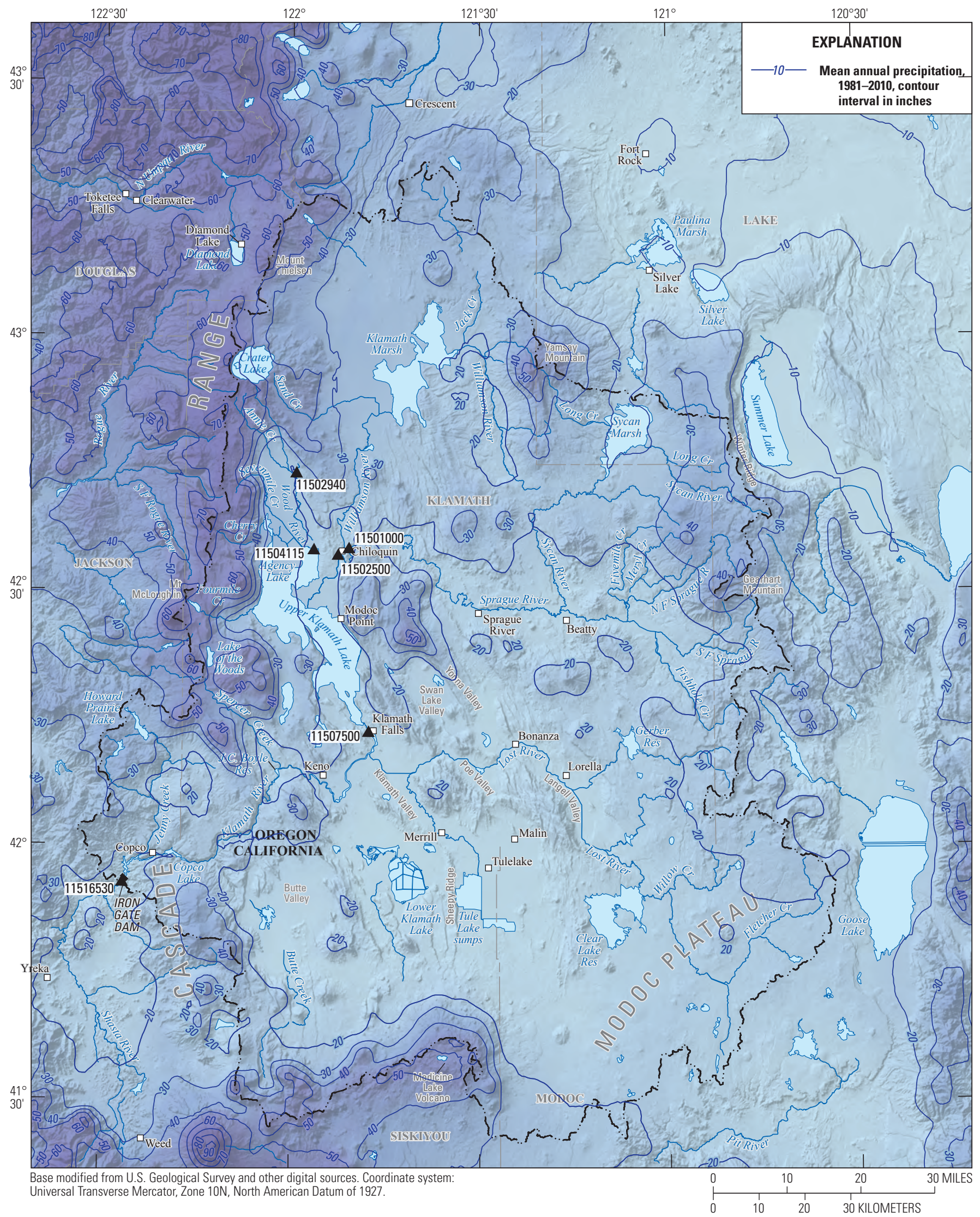

Figure 2. Mean annual precipitation in the Upper Klamath Basin, Oregon and California, 1981-2010. Data from PRISM Climate Group (2018). 


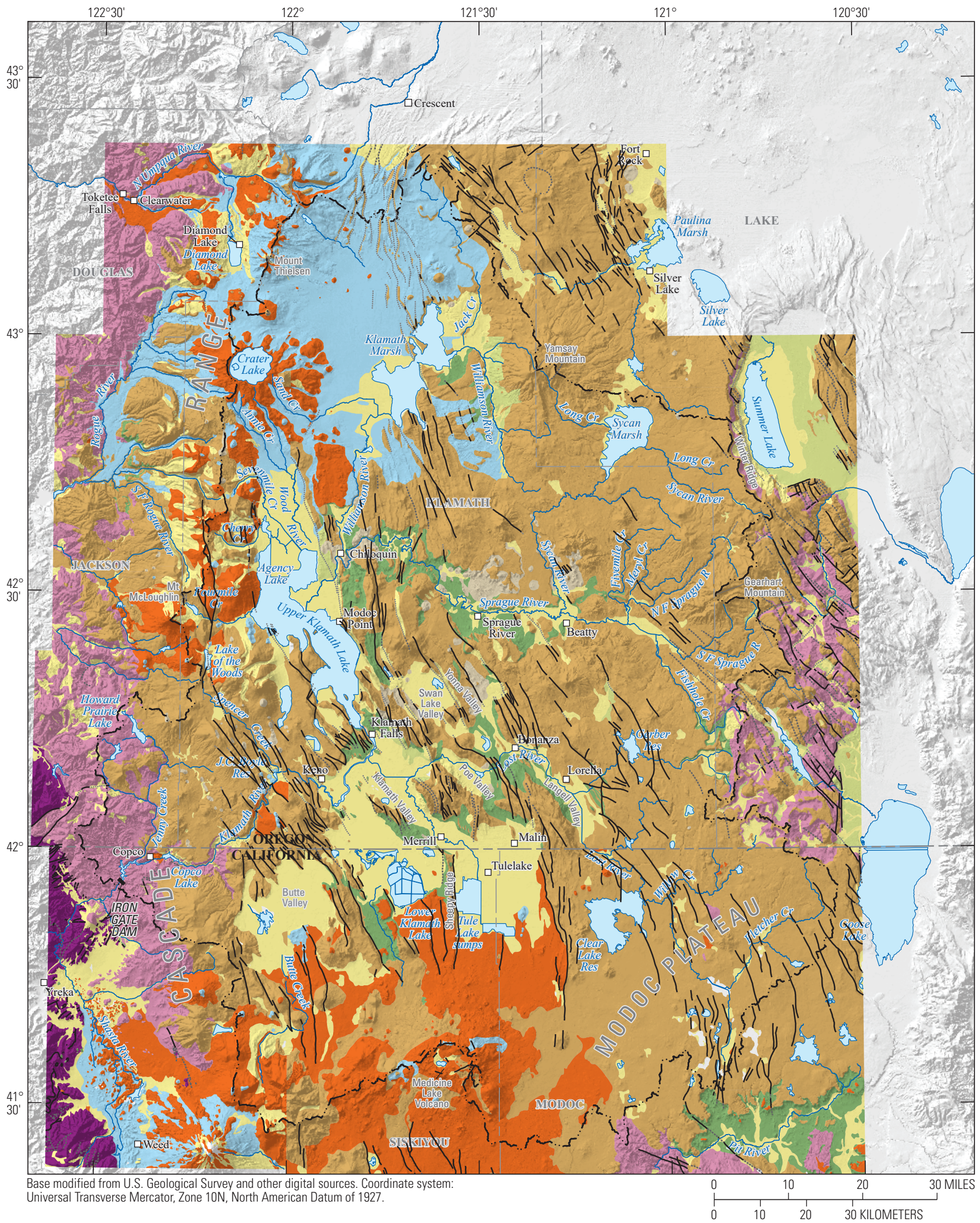

Figure 3. Geology in the Upper Klamath Basin, Oregon and California. 


\section{EXPLANATION}

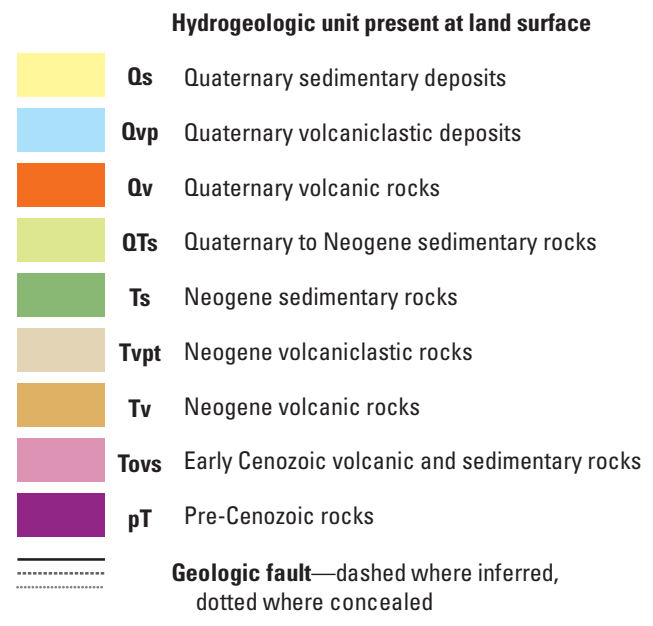

NOTE: Geology generalized from Gannet and others (2012)

\section{Figure 3.-Continued}

Snowfall historically represents about 30 percent of the annual precipitation in the valleys and more than 50 percent of precipitation at higher elevations (Taylor and Hannan, 1999). However, these percentages will probably decrease under future warming trends. Snowpack usually increases with elevation. However, because the UKB has a decreasing precipitation gradient from west to east there usually is a corresponding decrease in snowpack from west to east. Winters and summers in the UKB are generally cold and warm, respectively. January mean-minimum and meanmaximum temperatures (1981-2010) at Crater Lake are 19.0 and $34.0^{\circ} \mathrm{F}$, and at Klamath Falls are 21.1 and $39.9^{\circ} \mathrm{F}$. July mean minimum and maximum temperatures (1981-2010) at Crater Lake are 40.2 and $69.9^{\circ} \mathrm{F}$ and at Klamath Falls are 46.3 and $83.2{ }^{\circ} \mathrm{F}$ (PRISM Climate Group, 2018).
Most of the UKB is located on the western fringe of the Basin and Range geologic province (Dicken and Dicken, 1985) and is characterized by strong relief (fig. 3). Extensive, broad, flat, poorly drained uplands, valleys, and marshlands are located throughout the province. The northern, eastern, and southern boundaries of the UKB are defined by Tertiary volcanoes, rims, scarps, buttes, and fault-block mountains; the western boundary is formed by the Tertiary to Quaternary Cascade Range volcanic arc. Generally, volcanic deposits, especially the younger Quaternary materials, are assumed to have higher permeability rates than sedimentary material. The basin containing UKL and Agency Lake is a fault-bounded trough, or graben (Gonthier, 1984). Much of the UKB has a poorly developed drainage system that includes many small streams that discharge into marshes and intermittent streams that disappear into pumice or porous lava. Soils in the UKB can be characterized as mostly loam and sand (Natural Resource Conservation Service, 2018). Approximately 70 and 30 percent of the cumulative land surface is loam and sand, respectively.

Major land use activities in the UKB include irrigated agriculture, ranching, and timber production, depending largely on elevation. Most of the irrigated agriculture areas are at lower elevations adjacent to the major rivers. Agriculture in the Williamson and Sprague River Basins is primarily irrigated pasture. In the Lost River Basin, located downstream and southeast of UKL, irrigation is used for crops such as oats, barley, wheat, potatoes, and sugar beets. In total, about 500,000 acres of agricultural land are irrigated in the UKB as of 2011 (Gannett and others, 2012). About 240,000 acres of this total are in the Project (U.S. Bureau of Reclamation, 2018). Rangelands are mainly on the tablelands, benches, and terraces. Forest is predominant on the slopes of the buttes and mountains. Livestock grazing can occur on irrigated pastureland, rangeland, and forestland throughout the basin. Although more than half of the UKB is forestland, it is not homogeneous; second- and third-growth stands occur in varying stages of regeneration. 


\section{Model Development}

The model used in this study and described in this report is the USGS Precipitation-Runoff Modeling System (PRMS), version 5.0 (Leavesley and others, 1983; Markstrom and others, 2008; Markstrom and others, 2015; Regan and LaFontaine, 2017).

\section{Description}

PRMS is a deterministic, distributed-parameter, physicalprocess-based modeling system that can simulate a suite of snow, evapotranspiration, surface-water, and groundwater processes on a daily time step. The model can be used to characterize the response of streamflow and physical processes in a basin to various combinations of climate and land-use conditions. The minimum input data required to simulate daily streamflow with PRMS include daily total precipitation and minimum and maximum daily air temperature. As shown in the schematic model diagram, these meteorological inputs near the surface drive energy and hydrologic processes throughout the basin (fig. 4). In addition to meteorological data, the model uses a parameter file that contains the values of coefficients in the model algorithms, which simulate basin processes. The values of these coefficients (or parameters) define the physical characteristics of the basin. Many of the parameters are spatially distributed, which makes it possible to characterize varying land- and sub-surface conditions in a basin. In PRMS, a basin is discretized into smaller spatial units having similar hydrologic response conditions. Called Hydrologic Response Units (HRUs), they are defined for a specific basin during the model development process. HRUs are typically based on physical characteristics such as land surface elevation, slope, aspect, vegetation type and cover, land use, soil characteristics, geology, drainage boundaries, distribution of precipitation, temperature, solar radiation, and flow direction (Markstrom and others, 2015). Energy and water balances are computed for each HRU on a daily time step. PRMS simulates the accumulation and melt of snowpack as well as evaporation and transpiration losses from an HRU on a daily basis. HRUs can be also be classified as a land or water body unit. In PRMS version 5.0, runoff generated from an HRU can pass through to a neighboring HRU or directly to a network of stream segments where streamflow is routed to the basin outlet.

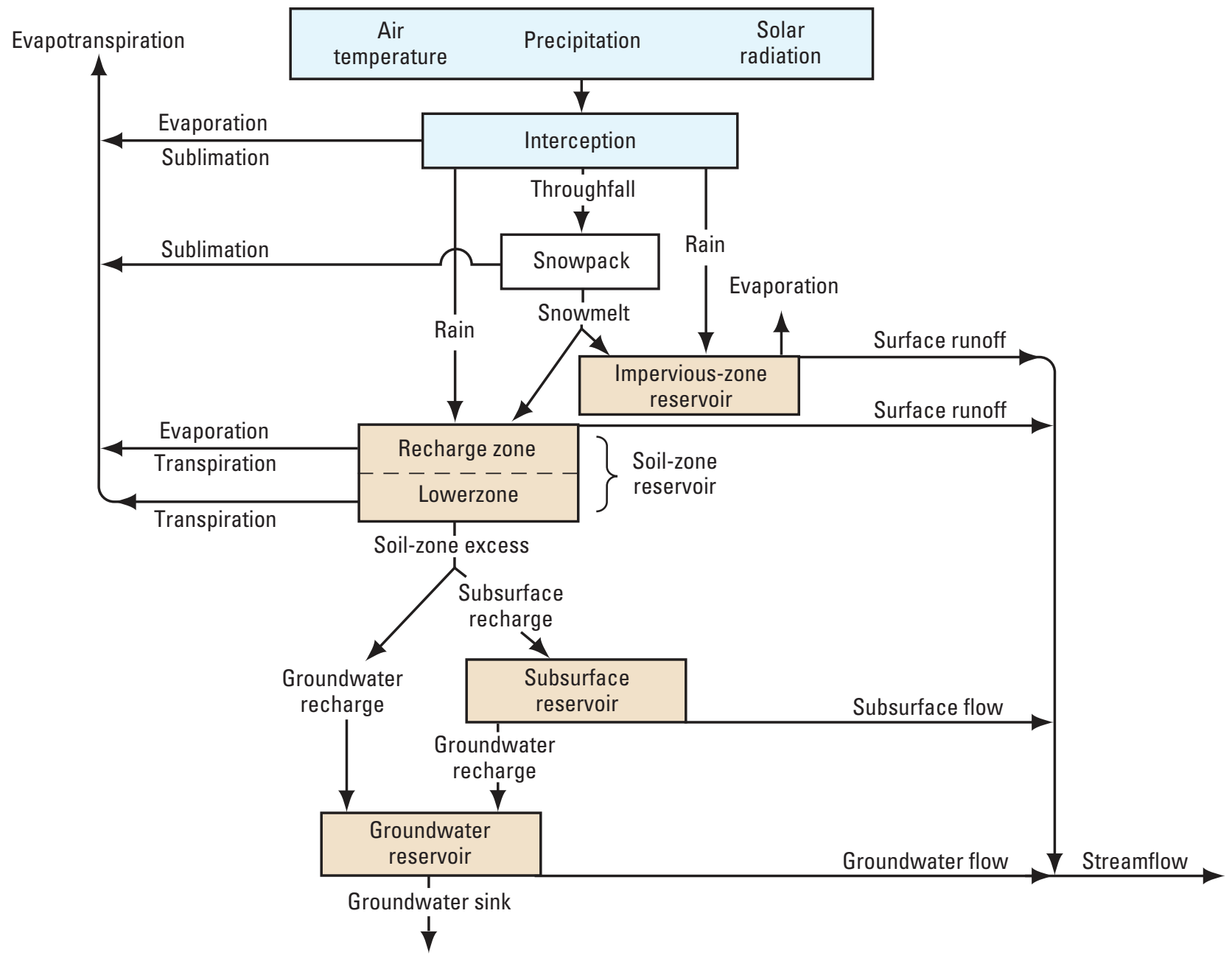

Figure 4. Schematic diagram of the Precipitation-Runoff Modeling System. 


\section{Delineation and Parameterization of Spatial Features}

The UKB PRMS model encompasses the drainage area upstream of Iron Gate Dam, California, approximately 8,300 $\mathrm{mi}^{2}$, which includes the internally drained Lost River and Butte Valley sub-basins. The initial framework for this model was derived from the Geospatial Fabric for the National Hydrologic Model (NHM), which included 175 HRUs and 88 stream segments for this same basin area (Viger, 2014; Viger and Bock, 2014; Reagan and others, 2018). Geographic information systems shape files were downloaded in February 2017 at U.S. Geological Survey (2019c). The NHM PRMS parameter and meteorological input files were also acquired in February 2017 from the USGS Earth Systems Modeling Branch (formerly the National Research Program).

The number of HRUs was increased to 403 to improve the representation of snowpack conditions at smaller elevation ranges because many of the larger HRUs created for the Geospatial Fabric straddled a large range of elevations (fig. 5). These HRUs were broken into smaller HRUs by bisecting them with the 5,000 and 6,000 ft contour elevation lines. HRU parameter values pertaining to area, aspect, mean elevation, and slope were recomputed. However, HRU parameter values pertaining to imperviousness, vegetation, interception, soils, geology, snow depletion, solar radiation, and evapotranspiration were the same as their corresponding NHM HRU parameters. The number of stream segments was increased to 95 to give model users more streamflow simulation locations.

The PRMS model for the entire UKB upstream of Iron Gate Dam was sub-divided into smaller basin models for calibration (table 1). The sub-basins upstream of the streamflow gages shown in table 1 are mostly nested with each other. For example, the Sprague River flows into the Williamson River. The Williamson and Wood Rivers flow into UKL separately. The Link River flows from UKL to the Klamath River. For this report, the drainage areas above the streamflow gage on the Link River at Klamath Falls (11507500) and UKL are used interchangeably because they are nearly the same. The model calibration strategy was to calibrate headwater basins first and then calibrate the next downstream basin and then the next after that. Calibrated HRUs in an upstream basin would then remain fixed during the calibration of downstream HRUs.

Parameters in PRMS that characterize basin physical characteristics have values that can be directly or indirectly estimated from geospatial data containing vegetation, soils, geology, topography information (table 2). These parameters were not adjusted during the calibration process because they are physical characteristics defined by the spatial data and assumed to be stationary. Most of these parameter values were already provided to the study in the NHM parameter file (Regan and others, 2018). When the NHM HRUs were discretized into new HRUs for this study, only the values for hru_area, hru_aspect, hru_elev, hru_slope, hru_lat, and hru_long had to be computed using digital elevation model (DEM) data (U.S. Geological Survey, 2019e).

\section{Model Input}

Meteorological input data needed to run the UKB PRMS model are daily precipitation and daily minimum and maximum air temperature.

\section{Measured Data}

Most of the meteorological stations within and surrounding the UKB are operated by the NWS and the NRCS. The NWS stations are part of the Cooperative Observer Program and typically measure daily precipitation and minimum and maximum air temperature. The NRCS stations are part of the SNOTEL network and measure precipitation and air temperature in addition to snow-water equivalence. Of the numerous meteorological stations in the UKB region, 32 had continuous and long-term daily records, most from 1980 to 2015, which made them suitable for hydrologic modeling (table 3; fig. 6). With the exception of Crater Lake, the NWS stations in the UKB are located near towns, or on farms, and at lower elevations from about 2,700 to $4,800 \mathrm{ft}$. However, NRCS SNOTEL stations in the UKB are located at higher elevations, from about 4,700 to 7,100 ft and usually just below a ridge line, but not on a ridge line. 


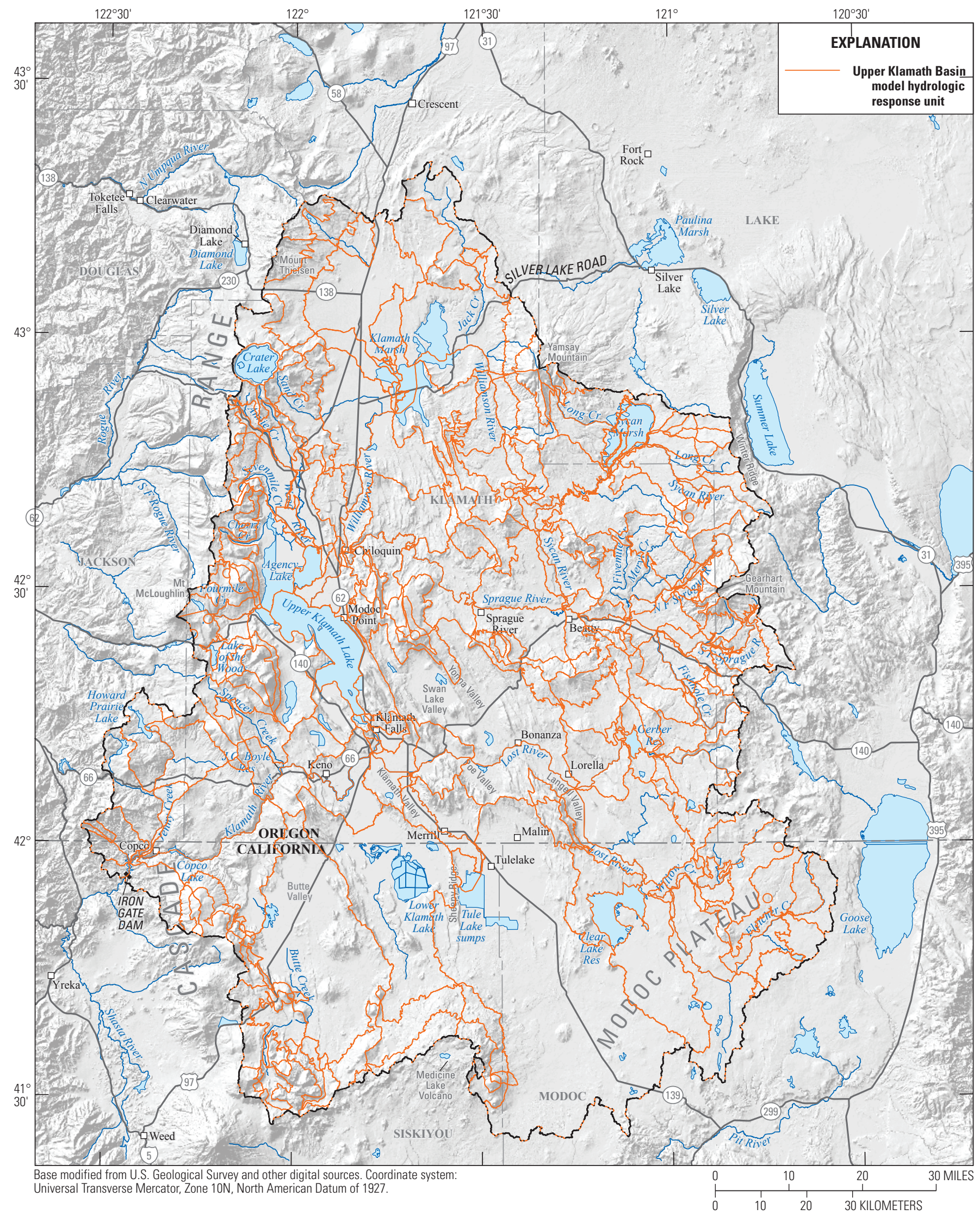

Figure 5. Upper Klamath Basin model hydrologic response units. 
Table 1. Streamgaging stations used for calibrating the Upper Klamath Basin Precipitation-Runoff Modeling System models.

[In this report, Link River at Klamath Falls (USGS streamgaging station 11507500 ) is used interchangeably with Upper Klamath Lake because their drainage areas are nearly same. Latitude and longitude is in decimal degrees. Elevation at streamgaging station is shown in feet above the National Geodetic Vertical Datum of 1929. Abbreviations: HRUs, hydrologic response units; mi² $^{2}$ square mile; USGS, U.S. Geological Survey; WY, water year]

\begin{tabular}{|c|c|c|c|c|c|c|c|c|c|}
\hline $\begin{array}{l}\text { Map } \\
\text { No. }\end{array}$ & $\begin{array}{c}\text { USGS } \\
\text { streamgaging } \\
\text { station } \\
\text { No. }\end{array}$ & Description & $\begin{array}{c}\text { Latitude } \\
\text { (north) }\end{array}$ & $\begin{array}{l}\text { Longitude } \\
\text { (west) }\end{array}$ & $\begin{array}{l}\text { Drainage } \\
\text { area } \\
\left(\mathrm{mi}^{2}\right)\end{array}$ & $\begin{array}{c}\text { Elevation } \\
\text { at } \\
\text { streamgaging } \\
\text { station } \\
\text { (foot) }\end{array}$ & $\begin{array}{l}\text { Period of } \\
\text { record used }\end{array}$ & $\begin{array}{l}\text { Upstream } \\
\text { HRUs }\end{array}$ & $\begin{array}{l}\text { Upstream } \\
\text { stream } \\
\text { segments }\end{array}$ \\
\hline 1 & 11501000 & $\begin{array}{l}\text { Sprague River near Chilo- } \\
\text { quin, Oregon }\end{array}$ & 42.5840 & 121.8486 & 1,565 & 4,202 & $\begin{array}{l}\text { WYs 1981- } \\
2015\end{array}$ & 130 & 25 \\
\hline 3 & 11502940 & $\begin{array}{l}\text { Wood River at Dixon Road } \\
\text { near Fort Klamath, } \\
\text { Oregon }\end{array}$ & 42.7322 & 121.9885 & 5.45 & 4,200 & $\begin{array}{l}\text { WYs 2003- } \\
2006\end{array}$ & 2 & 1 \\
\hline 4 & 11504115 & $\begin{array}{l}\text { Wood River near Klamath } \\
\text { Agency, Oregon }\end{array}$ & 42.5816 & 121.9417 & 107 & 4,147 & $\begin{array}{l}\text { WYs 2014- } \\
2015\end{array}$ & 14 & 4 \\
\hline
\end{tabular}

${ }^{1}$ Includes internally drained Lost River and Butte Valley subbasins.

Table 2. Precipitation Runoff Modeling System model parameter values determined from geospatial data.

[Parameter values determined from measured geospatial data. Abbreviation: HRU, hydrologic response unit]

\begin{tabular}{lll}
\hline \multicolumn{1}{c}{ Parameter } & \multicolumn{1}{c}{ Description } & \multicolumn{1}{c}{ Process } \\
\hline jh_coef_hru & Jensen-Haise HRU air temperature coefficient & Evapo-transpiration \\
snow_intcp & Snow interception storage capacity & Interception \\
srain_intcp & Summer rain interception storage capacity & Interception \\
wrain_intcp & Winter rain interception storage capacity & Interception \\
rad_trncf & Solar radiation transmission coefficient & Snow \\
snarea_thresh & Maximum threshold water equivalent for snow depletion & Snow \\
soil_type & Soil type & Soilzone \\
hru_slope & HRU slope & Solar radiation \\
cov_type & Vegetation cover type & Surface \\
covden_sum & Summer vegetation cover density & Surface \\
covden_win & Winter vegetation cover density & Surface \\
hru_area & HRU area & Surface \\
hru_aspect & HRU aspect & Surface \\
hru_elev & HRU mean elevation & Surface \\
hru_lat & HRU latitude & Surface \\
hru_lon & HRU longitude & Surface \\
hru_percent_imperv & HRU percent impervious & Surface \\
hru_type & HRU land type & Surface \\
\hline
\end{tabular}


Table 3. U.S. National Weather Service and Natural Resources Conservation Service meteorological stations used in the model.

[Latitude and longitude is in decimal degrees. Abbreviations: NRCS, U.S. Natural Resources Conservation Service; NWS, National Weather Service]

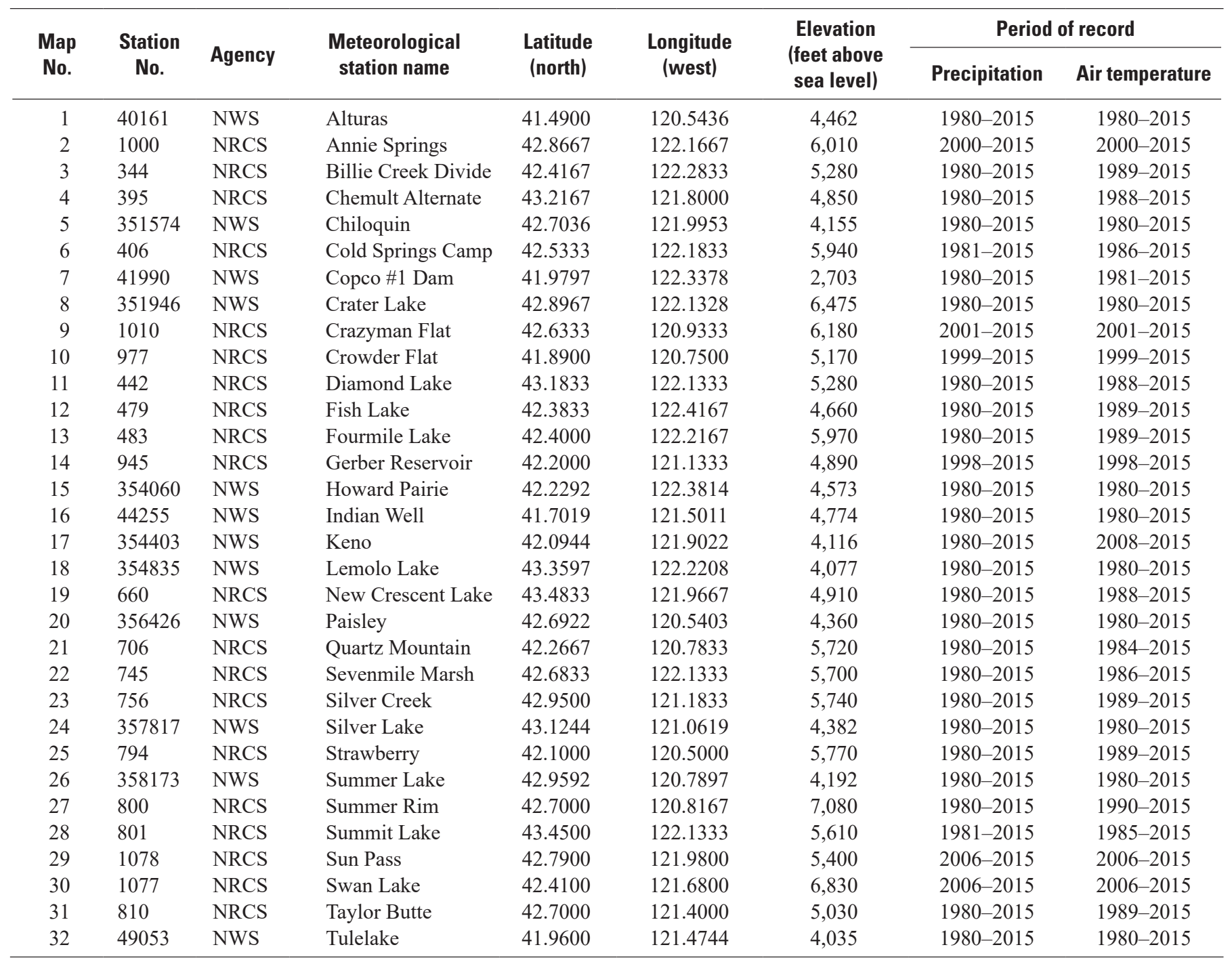




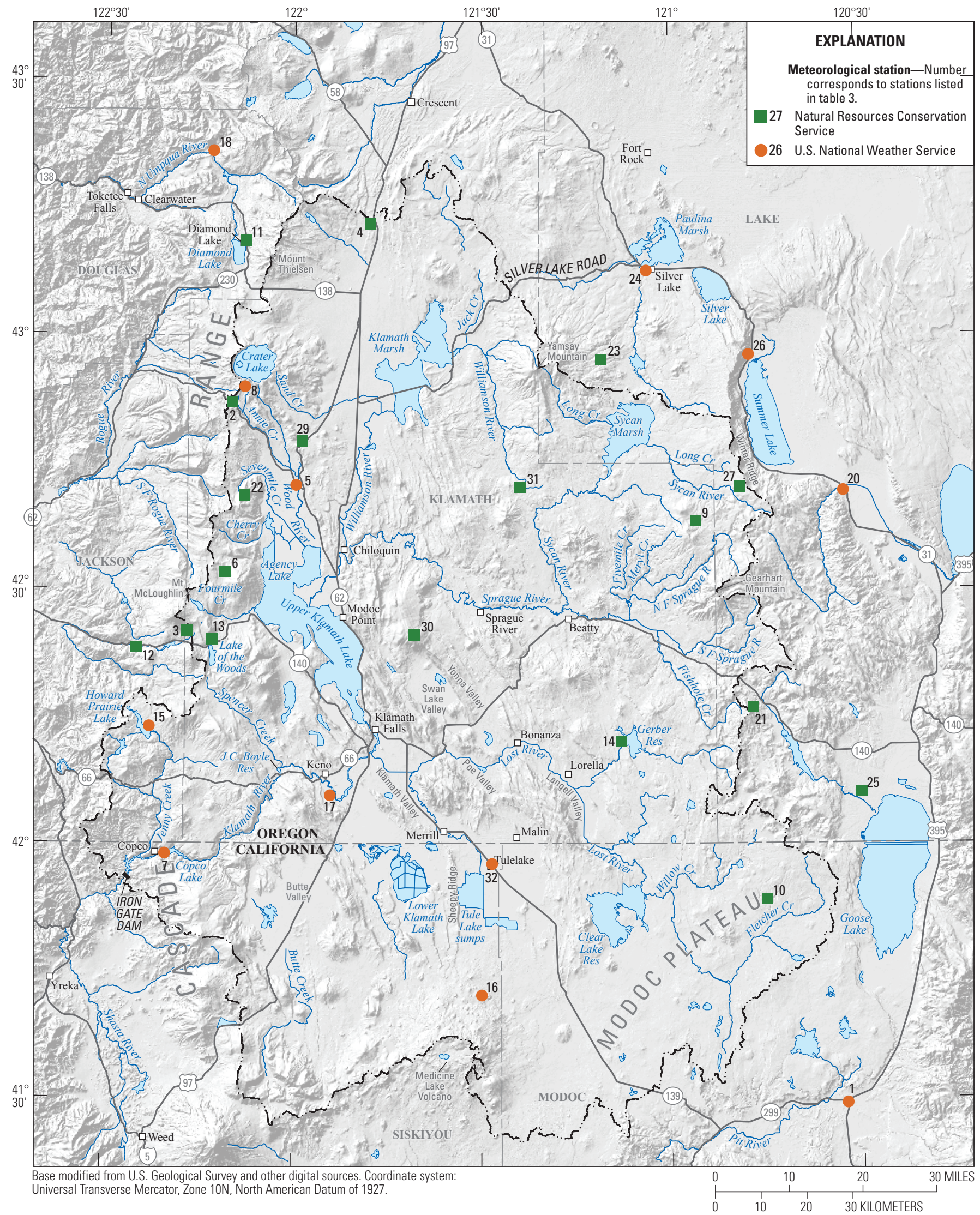

Figure 6. U.S. National Weather Service and Natural Resources Conservation Service meteorological stations. Numbers shown in the map correspond to stations listed in table 3. 


\section{Data Distribution Methodology}

PRMS version 5.0 provides various methods of distributing data from a meteorological station to an HRU. Earlier versions of PRMS required assigning each HRU to specific observation station time series and using precipitation weighting coefficients and air temperature lapse rates to compensate for the elevation differences between the station and the HRU. More recent versions of PRMS include a climate-by-HRU input time series data method. In this method, every HRU has its own individual daily precipitation and air temperature time series. These time series can be created using gridded meteorological datasets, such as Parameter-elevation Regressions on Independent Slopes Model (PRISM) (PRISM Climate Group, 2018) or Daymet (Thornton, 1997; Thornton and others, 2016), and geographic information systems technology to compute a weightedaverage time series for each HRU. This approach could not be used to construct and calibrate the UKB PRMS model because PRISM and Daymet gridded data sets are not available (at the time of this study) on a real-time basis, which is essential for streamflow forecasting. Fortunately, daily data from the 32 meteorological stations in the UKB are accessible online on a real-time basis (previous or current day). To distribute real-time measured station data to individual HRUs, the USGS Draper Climate-Distribution Software was used (Donovan and Koczot, 2019; Koczot and others, 2005). The name "Draper" refers to the mathematic draping of a spatially distributed data over measured point values. Draper constructs climateby-HRU data (precipitation and minimum/maximum air temperature) files that are formatted for PRMS input. These files include a separate time series for each HRU, which is derived from the measured time series data. This method made it possible to keep the meteorological data sets used for both model calibration and real-time streamflow forecasting consistent with each other.

In addition to the manual by Donovan and Koczot (2019), information on using Draper in a real-time streamflow forecasting application with the UKB PRMS model is provided in appendix 1 . In a forecasting application, the forecaster needs to create only three files containing measured daily precipitation, minimum air temperature, and maximum air temperature. The number and ordering of data columns (32) in each file must be identical to the stations in table 3. The period of record for these files should include a sufficient spin-up period (typically 3 years or more) up to the current date when the forecast is made. Other Draper input files were already created for the model calibration and do not need to be recreated for a forecasting application. These previously constructed files include the minimum and maximum range for each meteorological parameter (precipitation, minimum air temperature, and maximum air temperature), mean-monthly values for 32 meteorological stations for 1980-2015 for each meteorological parameter, mean-monthly values for the 403 HRUs for 1980-2015 for each meteorological parameter, latitude and longitude of the 32 meteorological stations, and latitude and longitude of the 403 HRU centroids. The meanmonthly values for the stations and HRUs were computed using Daymet data (1-kilometer [km] resolution) (Thornton, 1997; Thornton and others, 2016). Additional files containing the monthly standard deviation for stations and HRUs were also computed using Daymet data for just maximum and minimum air temperature.

\section{Model Calibration}

Model calibration involves adjusting parameter values for the purpose of minimizing error between simulated output and measured data. In addition to measured daily streamflow data, the calibration of the UKB PRMS model also involved matching simulated and independently derived solar radiation, potential evapotranspiration, and snowpack data.

\section{Streamflow Adjustment}

For watershed model streamflow calibration, it is preferable to use measured daily streamflow records that are as natural as possible and unaltered by dam regulation or withdrawals for irrigation or water supply. Daily streamflow records used in the study were impacted by surface-water and groundwater irrigation withdrawals in their upstream drainage basins during the late spring and summer months. For this study, net consumptive-use volumes (irrigation withdrawals and return flows) were added to the measured daily streamflow records for three basins before they were used in PRMS model calibration to make their hydrographs more "naturalized." Basins for which measured streamflow data were naturalized include the Sprague River near Chiloquin (USGS streamgage 11501000), Williamson River below Sprague River near Chiloquin (USGS streamgage 11502500), and Link River at Klamath Falls (USGS streamgage 11507500) (table 4).

The net consumptive use volumes were based on irrigation acreage and monthly net consumptive-use rates estimated for the 2014 Upper Klamath Basin Comprehensive Agreement (State of Oregon, 2014). The agreement included acreage and rates based on 2004 (dry year) and 2006 (wet year) conditions. Average monthly net consumptive use volumes were computed by averaging the volumes of both years. After the monthly net consumptive use volumes, in cubic feet per second $\left(\mathrm{ft}^{3} / \mathrm{s}\right)$, were added to the measured daily streamflow time series for the three calibration basins they were smoothed using a 30-day moving average. 
Table 4. Streamflow adjustments for net consumptive use.

[In this report, Link River at Klamath Falls (USGS streamgaging station 1507500) is used interchangeably with Upper Klamath Lake because their drainage areas are nearly same. The shaded bars show the sums of the numbers in all unshaded lines above them. Estimates were derived from the 2014 Upper Klamath Basin Comprehensive Agreement (State of Oregon, 2014). Modec Point Canal diversion estimates were used for water years 1981-2008 for the Williamson River record (U.S. Geological Survey streamgaging station 11502500) and for the entire Link River record (U.S. Geological Survey streamgaging station 11507500). Abbreviation: $\mathrm{ft}^{3} / \mathrm{s}$, cubic foot per second]

\begin{tabular}{|c|c|c|c|c|c|c|c|c|}
\hline \multirow{2}{*}{ Basin description } & \multicolumn{8}{|c|}{ Net consumptive-use streamflow adjustments $\left(\mathrm{ft}^{3} / \mathrm{s}\right)$} \\
\hline & March & April & May & June & July & August & Sept. & October \\
\hline Sycan River sub basin & 0 & 47 & 55 & 76 & 94 & 57 & 14 & 5 \\
\hline Lower Sprague River sub basin & 0 & 24 & 54 & 89 & 103 & 90 & 60 & 16 \\
\hline 11501000 Sprague River near Chiloquin, Oregon & 0 & 82 & 152 & 244 & 288 & 224 & 121 & 33 \\
\hline Modoc Point canal diversion & 2 & 9 & 27 & 30 & 44 & 38 & 25 & 7 \\
\hline 11502500 Williamson River below Sprague River near Chiloquin, Oregon & 2 & 120 & 294 & 487 & 577 & 468 & 273 & 72 \\
\hline Williamson River below Sprague River sub basin & 0 & 4 & 13 & 18 & 24 & 21 & 12 & 6 \\
\hline Wood River & 0 & 0 & 5 & 24 & 52 & 70 & 59 & 19 \\
\hline 11507500 Link River at Klamath Falls, Oregon & 2 & 124 & 312 & 529 & 654 & 559 & 344 & 97 \\
\hline
\end{tabular}

In addition to net consumptive use rates from the Upper Klamath Basin Comprehensive Agreement, it was also necessary to account for diversions to the Modoc Point Canal. Monthly canal diversions estimates were provided by Jonathan LaMarche (Oregon Department of Water Resources, written commun., 2017). These canal flow estimates were added to the Williamson River below Sprague River near Chiloquin (11502500) and Link River at Klamath Falls (11507500) streamflow records in addition to net-consumptive use (table 4). However, the canal flow estimates were not added to the Williamson River record after July 2008 when the point of diversion to the canal was moved from above the Williamson River gage to downstream of the gage.

To calibrate a PRMS model capable of simulating inflows to UKL, it was necessary to construct a naturalized daily time series of total inflow draining to UKL. This would also be almost equivalent to a naturalized daily streamflow time series at the Link River gage 11507500 if UKL, Link River Dam, and the A Canal diversions did not exist. For this report, the UKB PRMS model was used to simulate runoff from all HRUs draining to UKL. However, the model does not simulate the daily fluxes and storage of the lake itself. Although a water body can be simulated in PRMS, that would have required using additional data sets and would have been outside of the scope of this phase of the study. In the UKB PRMS model, the hru_type parameter for UKL HRU (HRU 395) was set to zero, which made it an inactive HRU.
For many years, the BOR and water managers have used a monthly time series of computed net inflow to the lake (which is not the same as naturalized streamflow draining to the lake). In its basic form, the equation to compute monthly net inflow is:

$$
\text { Qnet inflow }=\Delta S+\text { Qoutflow }
$$

where,

Qnet inflow is net inflow to the lake, $\Delta S$ is the change in storage, and

Qoutflow is total flow leaving the lake through the Link River Dam and the A Canal. Change in storage $(\Delta S)$ can be written as the sum of all water entering and leaving the lake:

$$
\begin{aligned}
\Delta S & =(\text { Precipitation }+ \text { Qinflow }) \\
& -(\text { Evaporation }+ \text { Qoutflow })
\end{aligned}
$$

where,

Precipitation is lake surface precipitation,

Qinflow is the sum of all surface and groundwater inflows to the lake, and

Evaporation is lake surface evaporation.

Using equation (2), equation (1) can be rewritten as:

$$
\begin{aligned}
& \text { Qnet inflow }=(\text { Precipitation }+ \text { Qinflow }) \\
& -(\text { Evaporation }+ \text { Qoutflow })+\text { Qoutflow }
\end{aligned}
$$


Solving for Qinflow is shown as:

$$
\text { Qinflow }=\text { Evaporation }+ \text { Qnet inflow }- \text { Precipitation }
$$

To naturalize this equation, total net consumptive use $(C U)$ losses in the basin and evapotranspiration losses from wetlands surrounding the lake are added, shown as:

$$
\begin{aligned}
& \text { Qinflow }=\text { Evaporation }+ \text { Qnet inflow } \\
& - \text { Precipitation }+C U+\text { Wetlands } E T
\end{aligned}
$$

Seven HRUs surrounding UKL, HRUs 72, 89, 96, 97 , 162,217 , and 250 , contain wetlands and are connected to the lake. It was necessary to account for excess evapotranspiration losses from these HRUs by adding it to the constructed naturalized streamflow record, similar to what was done with consumptive use, because it was not feasible to simulate wetland evapotranspiration loss within PRMS. In PRMS, an HRU is either a land body or a water body. If it is a water body, it is necessary to precisely simulate the daily operation of UKL as a reservoir, which was outside of the scope of this phase of the project. If the HRU is a land body, PRMS simulates actual evapotranspiration as limited by precipitation input to the HRU. In reality, the seven wetland HRUs would have greater evapotranspiration loss because there is more available water in a wetland. By assuming that evapotranspiration was equal to potential evapotranspiration, evapotranspiration loss in excess of what PRMS already simulates from these HRUs could be accounted for by adding the difference between simulated evapotranspiration and simulated potential evapotranspiration to the constructed naturalized streamflow record before the model calibration.

To construct the daily Qinflow (eq. 5) time series, a pre-calibrated version of the UKB PRMS model was used to simulate daily lake evaporation (HRU 395), wetlands evapotranspiration (seven wetlands HRUs), and lake precipitation (HRU 395) for WYs 1981-2015. In the pre-calibrated version of the model, the potential evapotranspiration parameters had already been calibrated and finalized using monthly National Oceanic and Atmospheric Administration (NOAA) evaporation atlas data and air temperature data, which is described in more detail in the following section. However, the daily precipitation for UKL HRU was simulated using unweighted rain and snow HRU parameters.

Other terms in equation 5 include monthly net consumptive use (CU) upstream of UKL (table 4), which was smoothed using a 30 -day moving average, and daily net inflows (Qnet inflow), which were provided to this study by the BOR (written communication, 2017). It should be noted that PRMS simulated streamflow from the Williamson River, Wood River, or other tributaries entering UKL are not used in equation 5 .

\section{Parameter Optimization}

Parameters that characterize basin physical characteristics were directly or indirectly determined from geospatial data sets containing information on vegetation, soils, geology, topography (table 2). These parameters were not adjusted during the calibration process because they represent physical characteristics that are derived from measured or independently derived geospatial data and assumed to be stationary throughout the simulation period. However, other model parameters needed to be adjusted to calibrate the model. The initial values of the calibration parameters were their default PRMS values or values provided in the NHM parameter file. Parameters pertaining to solar radiation and potential evapotranspiration were manually calibrated because they were fewer in number. However, parameters pertaining to runoff and snowpack were more efficiently calibrated using an optimization program.

\section{Shortwave Solar Radiation}

For the UKB, PRMS daily short-wave solar radiation is computed using the modified degree-day method (Markstrom and others, 2015). Model parameters dday_slope and dday_intcp were dimensioned by month and HRU and had been previously calibrated in the NHM version of PRMS (Reagan and others, 2018). In their calibration they compared simulated shortwave radiation for the NHM HRUs against mean-monthly solar radiation compiled for continental United States by National Renewable Energy Laboratory (NREL) (Wilcox, 2012, National Renewable Energy Laboratory, 1992). For the UKB PRMS model, it was necessary to refine this calibration because the HRUs had been modified and different meteorological forcing data were used. Spatially weighted-average mean-monthly NREL solar radiation values were acquired for the 403 UKB PRMS model HRUs using the USGS Geo Data Portal (GDP) (Blodgett and others, 2011; USGS, 2019b). For each of the basins (table 1), basin area-weighted average shortwave radiation basin_potsw was simulated for WYs 1981-2015 using the Draper meteorological input data sets. Minor iterative adjustments were made to the $\boldsymbol{d d a y}_{\mathbf{S}}$ slope parameter using a multiplier for each month until the simulated and NREL mean-monthly solar radiation values closely matched for each of the basins (fig. 7). However, the previously calibrated NHM values for the $\boldsymbol{d d a y}_{-}$ intcp parameter were not adjusted. 


\section{Potential Evapotranspiration}

The Jensen-Haise method was used to simulate potential evapotranspiration (PET), which computes PET as function of air temperature and model simulated solar radiation (Jensen and Haise, 1963; Markstrom and others, 2015). Two parameters used in the method, $\boldsymbol{j h} \_$coef and $\boldsymbol{j h} \_$coef_hru, had been previously calibrated in the NHM version of PRMS (Reagan and others, 2018). For that calibration, they used mean-monthly values from an evaporation atlas compiled by the NOAA for the continental United States (Farnsworth and Thompson, 1982; Farnsworth and others, 1982). However, the calibration had to be refined for the UKB PRMS model because the HRUs had been modified and different meteorological forcing data were used. Spatially weightedaverage mean-monthly evaporation atlas values were acquired for the 403 UKB PRMS model HRUs using the GDP (Blodgett and others, 2011; U.S. Geological Survey 2019b). For each of the basins (table 1), basin area-weighted average potential evapotranspiration basin_potet was simulated for WYs 1981-2015 using the Draper meteorological input data sets. Minor iterative adjustments were then made to the jh_coef parameter using a multiplier for each month until the simulated and mean-monthly NOAA evaporation values closely matched for each of the basins (fig. 8). However, the previously determined NHM values for the $\boldsymbol{j}_{\boldsymbol{h}} \boldsymbol{c} \boldsymbol{c o e f} \mathbf{h} \boldsymbol{r} \boldsymbol{u}$ parameter were not adjusted.

\section{Runoff}

Runoff and snow-related parameters were calibrated using a combination manual adjustment and the PRMS parameter optimization program Let Us Calibrate (LUCA) (Hay and Umemoto, 2006). LUCA performs a multipleobjective, stepwise calibration of the parameters. The program

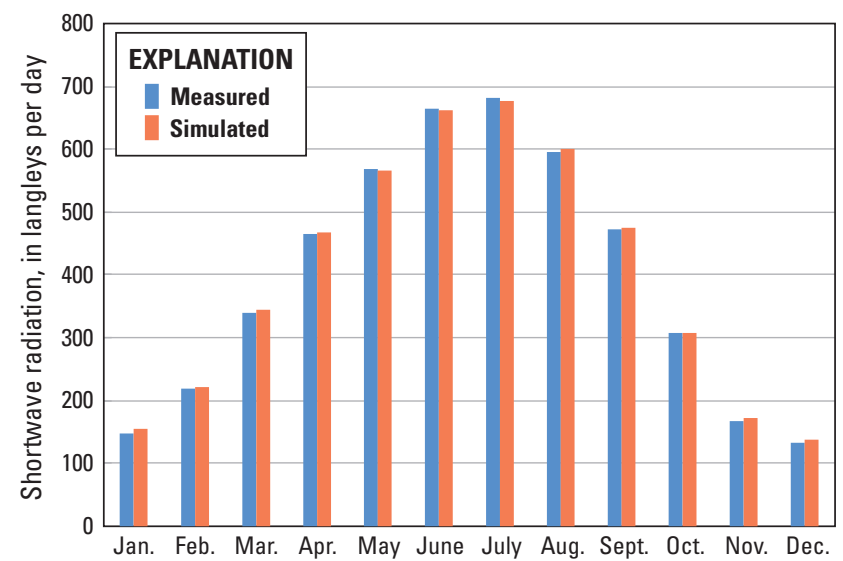

Figure 7. Measured and simulated mean-monthly shortwave radiation for the Upper Klamath Lake basin, Oregon, water years 1981-2015. uses the Shuffled Complex Evolution (Duan and others, 1993) global search algorithm to calibrate model parameters. Markstrom and others (2016) provide insights into PRMS parameter sensitivity for various hydrologic and climatic conditions within the United States. Ideally, PRMS parameters that are highly sensitive are used in LUCA optimization runs.

For this study, LUCA was used only for the Sprague River, Williamson River, and Link River (UKL) basin model calibrations. The two Wood River basins models did not have sufficient long-term measured daily streamflow records needed for the optimization. The Klamath River below Iron Gate Dam basin was also not used in LUCA because a naturalized daily streamflow record was unavailable. The LUCA runs for the Sprague River, Williamson River, and UKL basins used the same optimization period of WYs 2000-15. LUCA performs parameter optimization using a series of steps and rounds. During each step, a group of parameters are optimized simultaneously. After a step is completed, the program goes to the next step and optimizes another group of parameters. When it has completed all the specified steps, the program starts a new round by returning the first step. For this study, a calibration strategy with four steps and six rounds were used in the optimization runs (table 5) (Lauren Hay, U.S. Geological Survey, written commun., 2017). In each step, an objective function defined as the normalized root mean square error (NRMSE) statistic is used with four separate parameter groups depending on the calibration goal (water balance, timing, high flows, or low flows). Minimum and maximum ranges for the parameter values were also preset. Before running LUCA, a streamflow subdivide utility program was used to create daily data files containing separate numerical codes for high or low flow days (Lauren Hay, U.S. Geological Survey, written commun., 2017). This file was an input file to LUCA in addition to the PRMS model input files.

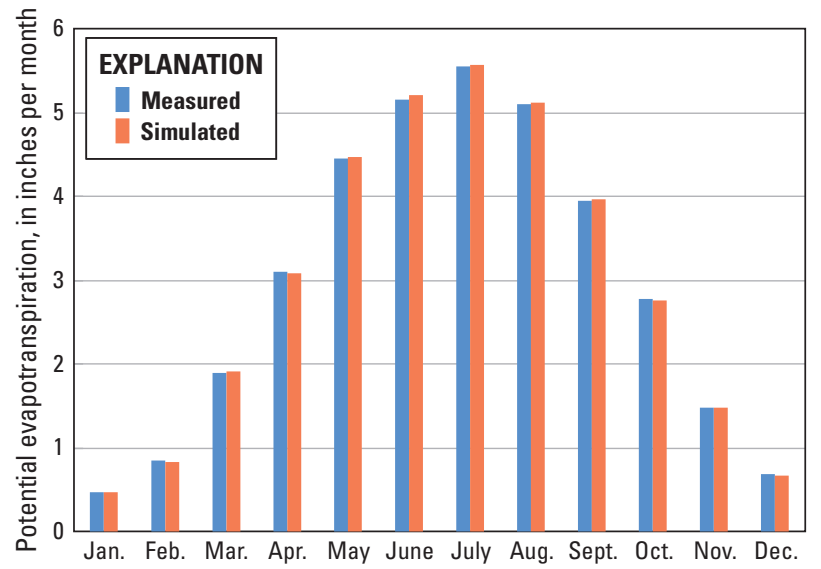

Figure 8. Measured and simulated mean-monthly potential evapotranspiration for the Upper Klamath Lake basin, Oregon, water years 1981-2015. 
Table 5. Precipitation Runoff Modeling System parameters and calibration steps using Let Us Calibrate (LUCA) for the Upper Klamath Basin model.

[Table is based on written comunication from Lauren Hay, U.S. Geological Survey, 2017. Abbreviations: ET, evapotranspiration; NRMSE, Normalized Root Mean Square Error; PRMS, Precipitation Runoff Modeling System]

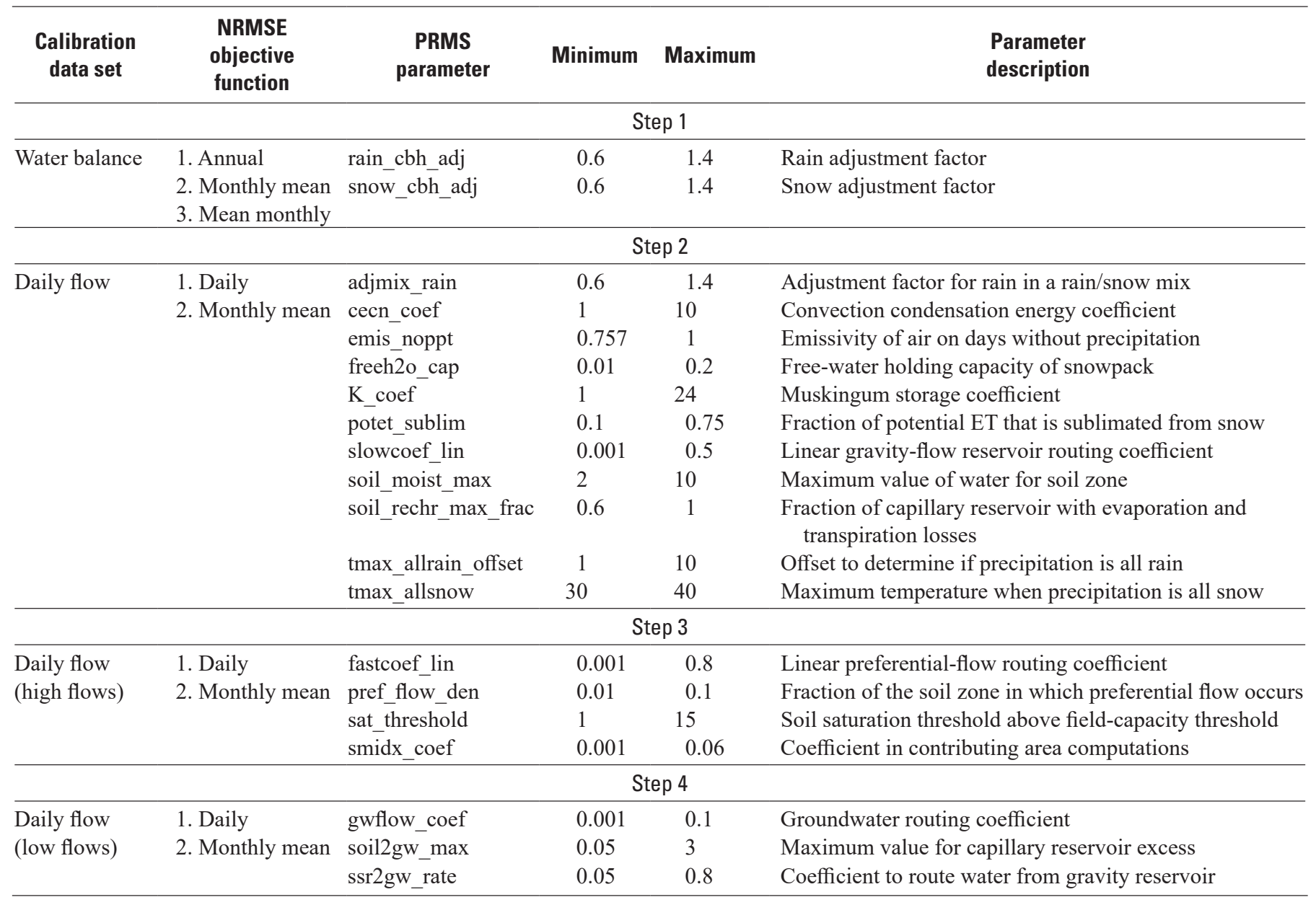

In addition to the LUCA calibration steps shown in table 5, additional LUCA optimization runs were made to improve low flows by further optimizing the parameters gwflow_coef, soil2gw_max, ssr2gw_rate, soil_moist_max, and slowcoef_sq using a single step and six rounds strategy.

\section{Snow-Water Equivalence}

Snow-water equivalence (SWE) data sets were indirectly used in the model calibration process with LUCA. After each LUCA optimization run, daily simulated SWE was compared with measured SWE data sets to assess the reasonableness of the precipitation and air temperature HRU adjustments at various elevations in the basin. While it was important to calibrate the model for both SWE and streamflow, a greater priority was placed on streamflow because of greater error in measured SWE data and because seasonal streamflow volume is the forecasting objective of the model. Available measured daily SWE data sets included SNOTEL data from various higher elevation locations and basin-weighted averaged Snow Data Assimilation System (SNODAS) data for the entire UKB (National Operational Hydrologic Remote Sensing Center, 2004).

Daily measured SWE at eight NRCS SNOTEL stations was compared with simulated SWE in the local HRU (fig. 9). The plots show results from WY 1986 to 2015 after a spin-up simulation period of WYs 1981-85. The plots generally show reasonable agreement in timing and volume. Although the measured SWE data are from SNOTEL stations and are spatially only points, the simulated SWE data were spatially averaged over a very small HRU area located at or next to the SNOTEL station. Thus, an exact match between measured and simulated SWE volumes was not expected. The plot also shows the variation in SWE volume at different elevations. However, SWE is not correlated with just elevation. Summer Rim SWE has less volume than Annie Springs SWE and is at a higher elevation. However, Annie Springs is located on the wetter west side, and Summer Rim is located on the drier east side, of the basin. 

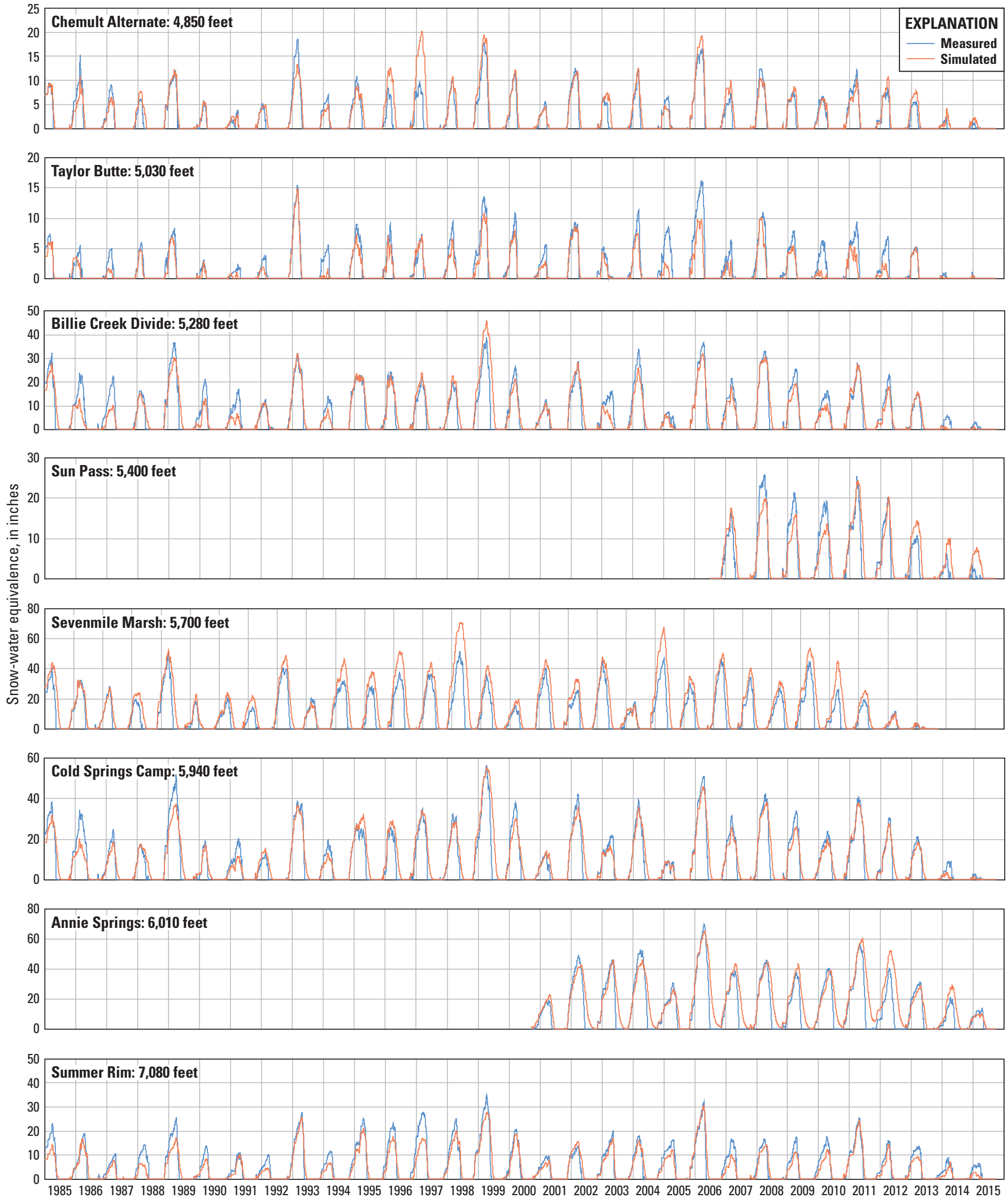

Figure 9. Measured and simulated daily snow-water equivalence at eight snow telemetry stations in the upper Klamath River Basin, Oregon and California, water years 1986-2015. Station names and their elevation above mean sea level are shown in each plot. Stations are listed in table 3 and locations shown in figure 6. Snow Telemetry (SNOTEL) stations are operated by the Natural Resources Conservation Service. 
Daily weighted-average SNODAS SWE data were compared with simulated daily SWE for the UKL basin for WYs 2004-13 (fig. 10). SNODAS SWE data are available for the conterminous United States at a 1-km square resolution. For this study, weighted-average daily SWE was computed for the model HRUs and the calibration basins using the GDP (Blodgett and others, 2011; U.S. Geological Survey, 2019b). As with the SNOTEL site comparisons (fig. 9), the volume of measured SNODAS SWE and simulated SWE did not always match. However, the timing of snowpack accumulation and depletion each year appeared excellent.

\section{Model Evaluation}

The Sprague River, Williamson River, and UKL basin PRMS models were evaluated with performance statistics and visually with plots that compared measured and simulated daily streamflow for the calibration and validation periods, WYs 2000-15 and WYs 1984-99, respectively (tables 6-7; figs. 11-16). Commonly used statistics in watershed modeling to evaluate simulation error include percent Bias, percent Relative error, and root-mean-square error (RMSE), which are defined as:

$$
\begin{gathered}
\text { Bias }=\frac{\sum(s-o)}{\sum o} \times 100 \\
\text { Relative Error }=\frac{\sum\left[\frac{(s-o)}{o}\right]}{N} \times 100 \\
\text { RMSE }=\sqrt{\frac{\sum(s-o)^{2}}{N}}
\end{gathered}
$$

where

$$
\begin{array}{cc}
S & \text { is simulated daily streamflow, in } \mathrm{ft}^{3} / \mathrm{s}, \\
o & \begin{array}{c}
\text { is observed (measured or constructed) daily } \\
\text { streamflow, in } \mathrm{ft}^{3} / \mathrm{s} \text {, and }
\end{array} \\
N & \text { is the number daily streamflow values. }
\end{array}
$$

Percent Bias describes the tendency of simulated values to be above or below measured values. A Bias of 0.0 is ideal. A positive or negative Bias indicates an over- or underestimation, respectively. Percent Relative Error is a measure of the error between simulated and measured values that has been normalized with the measured values. Relative Error of 0.0 is also ideal and positive or negative Relative Error indicates an over- or under-estimation, respectively. $\boldsymbol{R} \boldsymbol{M S} \boldsymbol{E}$ provides a measure of the magnitude of simulation errors in the units of the data and has not been normalized.

Statistics were computed annually, monthly, and for the October-March and April-September periods. Because the models were created for seasonal streamflow forecasting in the spring and summer, it was important to have a satisfactory calibration for the April-September period. With the exception of the October-March period, the percent Bias statistics were all plus or minus 5-percent for both the calibration and validation periods (tables 6-7).

Figures 11-13 show adjusted measured and simulated daily streamflow, for the Sprague River, Williamson River, and UKL basin, respectively, for the calibration period (WYs 2000-15). On a daily basis, the Sprague River visually shows a better calibration than the other plots. Because the Williamson River and UKL basin models were downstream, their naturalized streamflow data that required greater adjustment for consumptive use losses. The larger influence of estimated consumptive use made simulating daily flows at these locations more challenging than for the Sprague River. Figures 14-16 show adjusted measured and simulated mean-monthly streamflow for the Sprague River, Williamson River, and UKL basin, respectively, for WYs 1984-2015. The Williamson River and UKL basin plots show some oversimulation for May and June. However, on a seasonal basis, the mean April-September streamflow for the entire period for all the basin models was balanced (table 8).

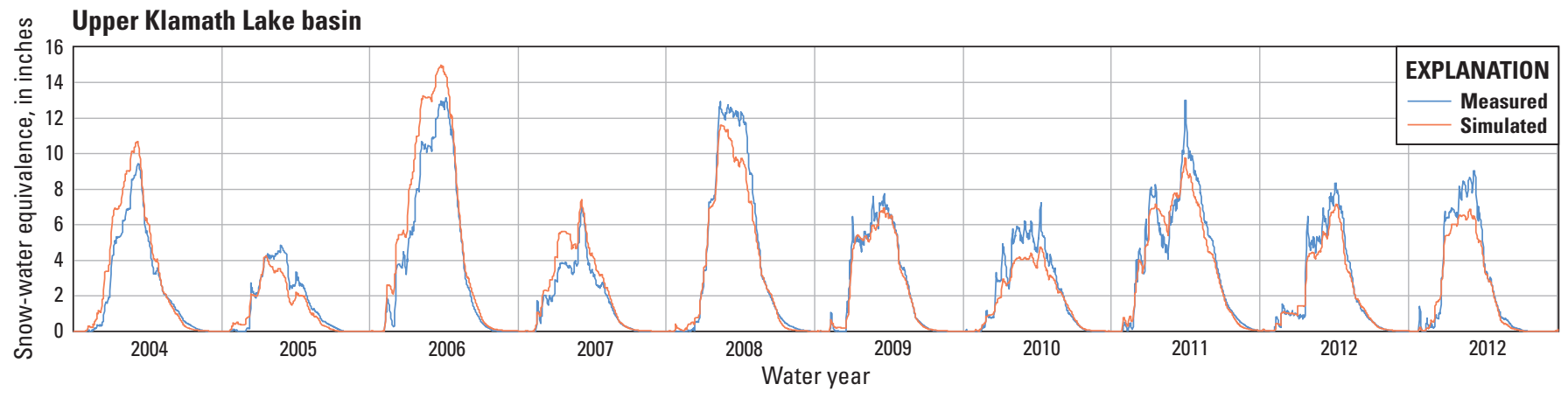

Figure 10. Measured and simulated daily snow-water equivalence for the Upper Klamath Lake basin, Oregon, water years 2004-13. 

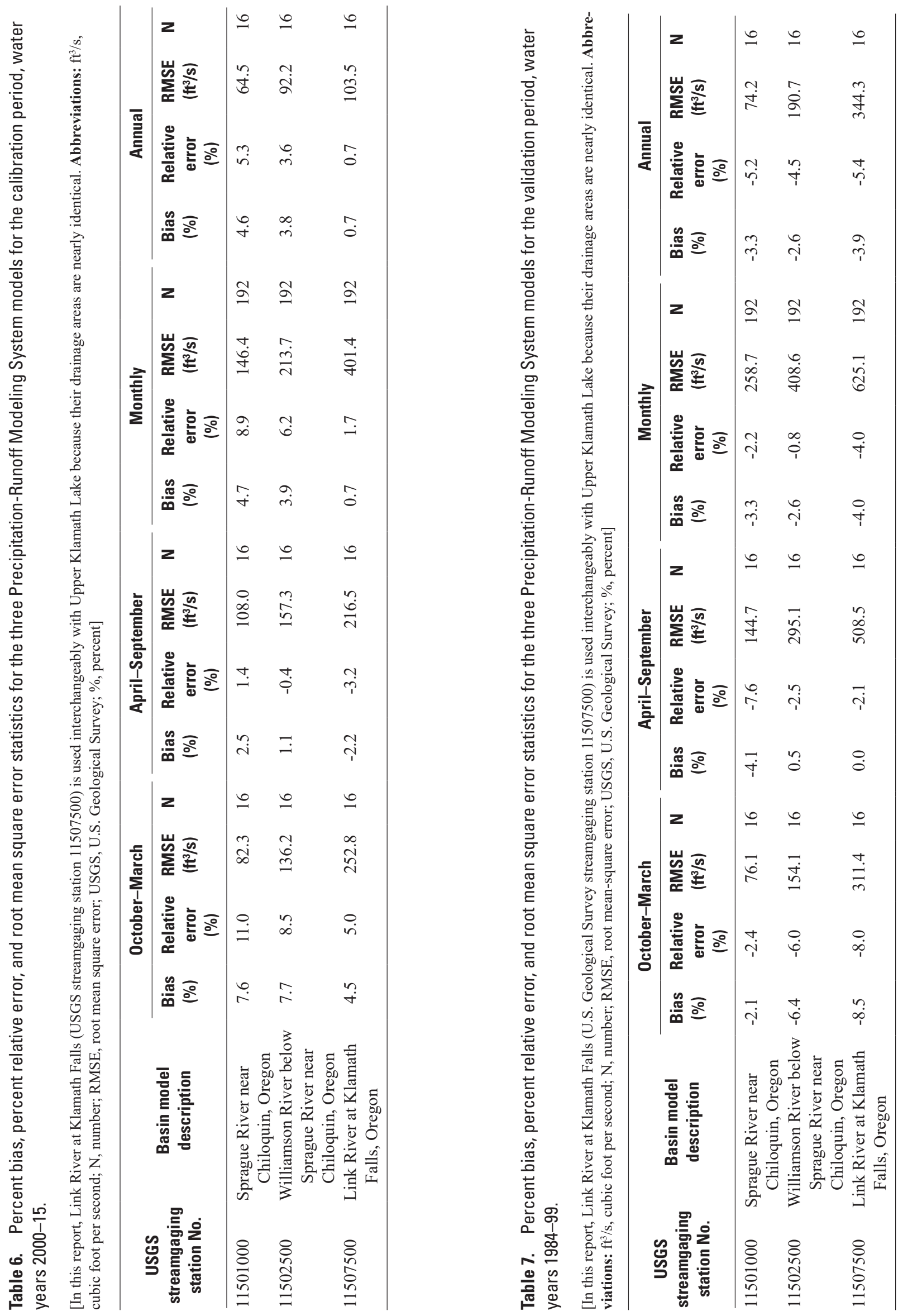


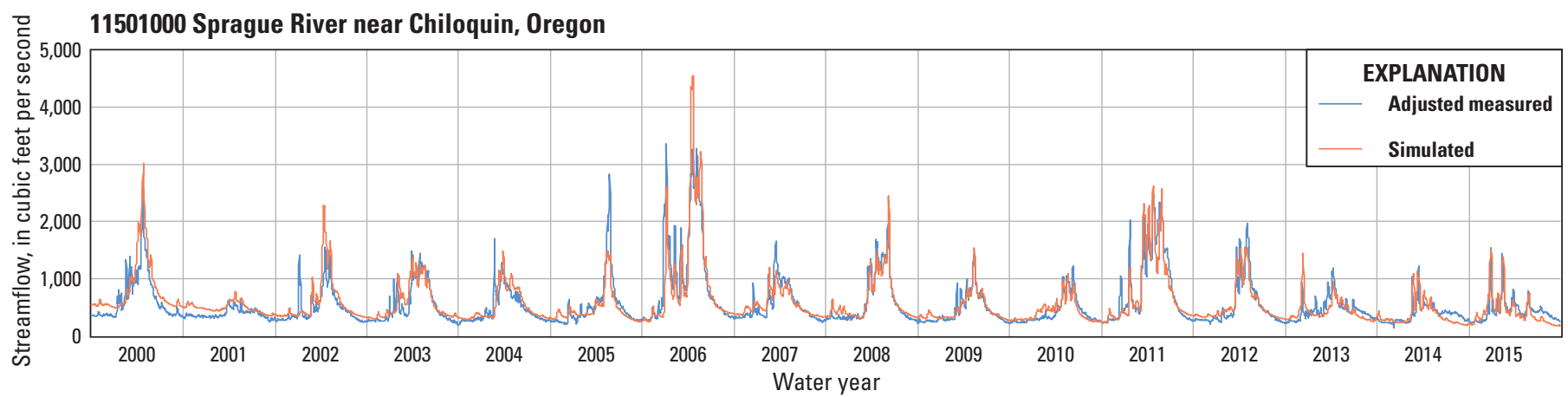

Figure 11. Adjusted measured and simulated daily streamflow at Sprague River near Chiloquin, Oregon (U.S. Geological Survey streamgage 11501000), for the calibration period, water years 2000-15.

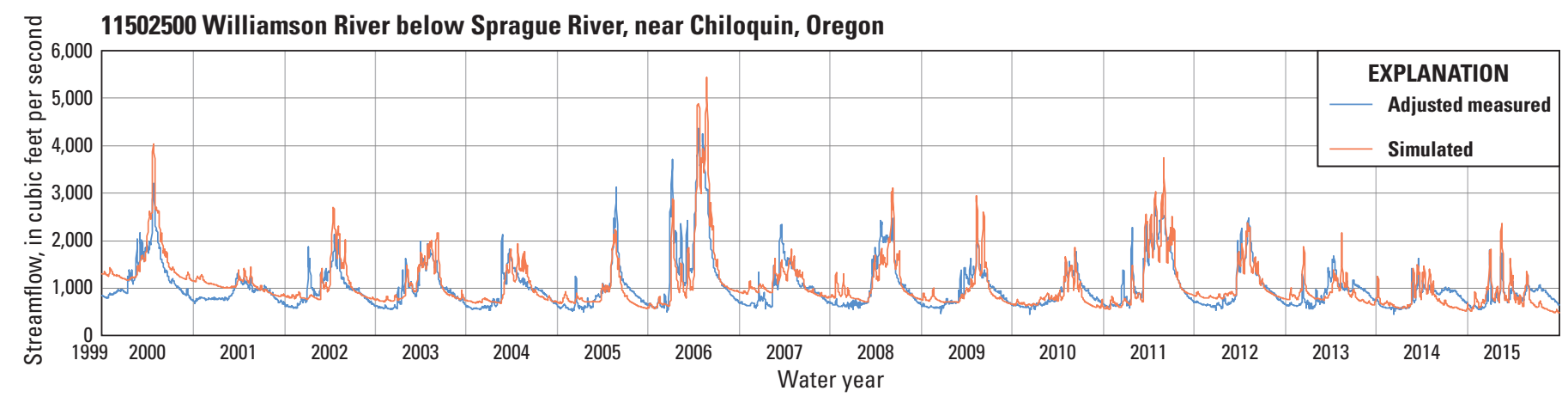

Figure 12. Adjusted measured and simulated daily streamflow at Williamson River below Sprague River, near Chiloquin, Oregon (U.S. Geological Survey streamgage 11502500), for the calibration period, water years 2000-15.

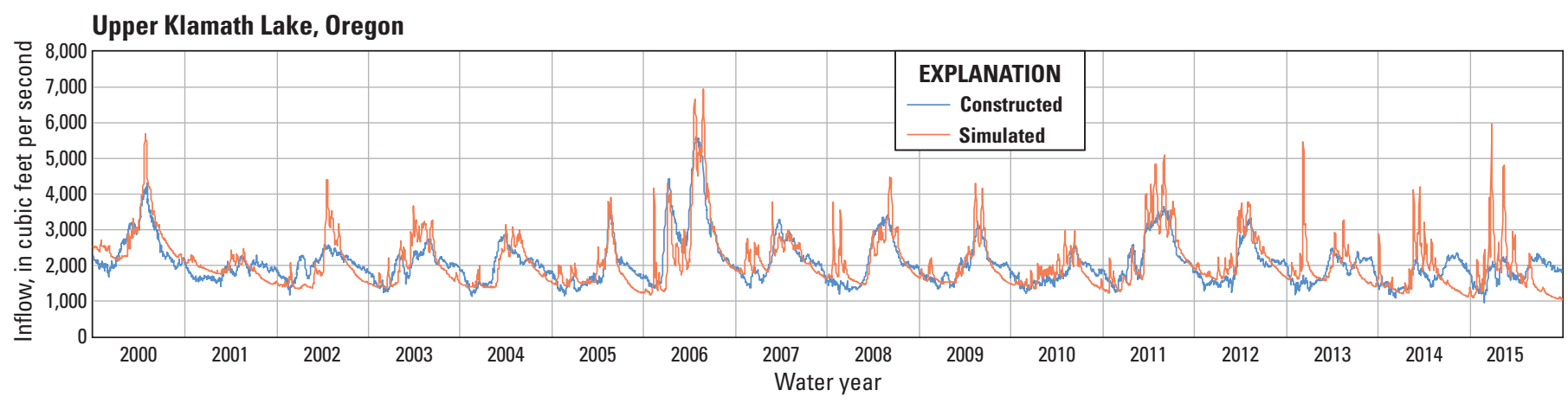

Figure 13. Constructed and simulated daily inflow to Upper Klamath Lake, Oregon, for the calibration period, water years 2000-15. 
11501000 Sprague River near Chiloquin, Oregon

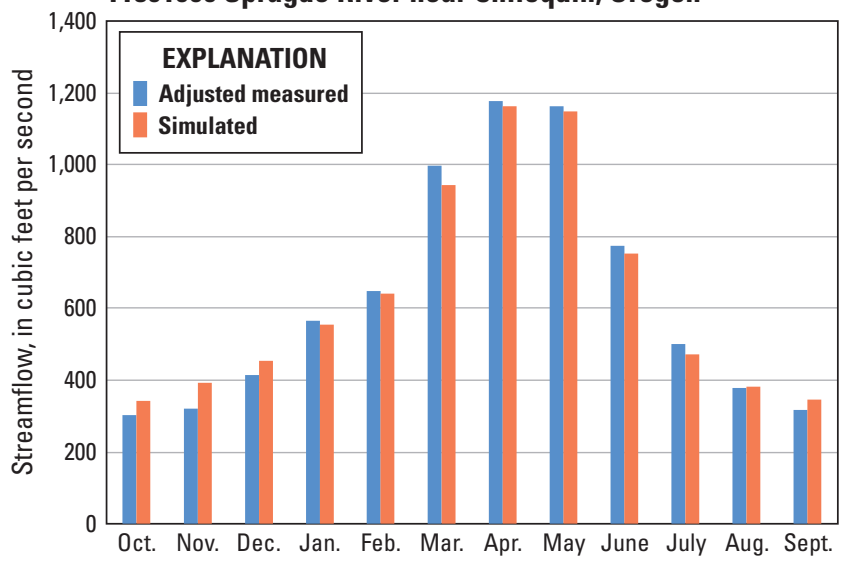

Figure 14. Adjusted measured and simulated meanmonthly streamflow at Sprague River near Chiloquin, Oregon (U.S. Geological Survey streamgage 11501000), water years 1984-2015.
11502500 Williamson River below Sprague River, near Chiloquin, Oregon

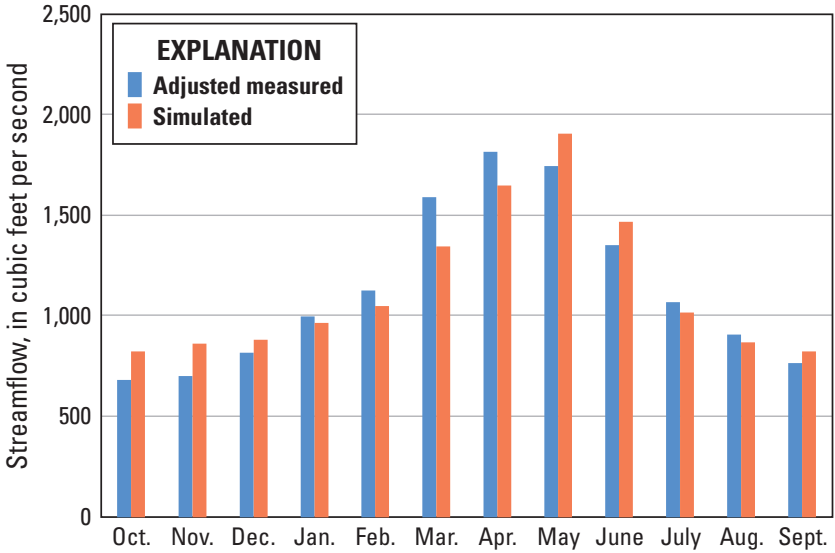

Figure 15. Adjusted measured and simulated meanmonthly streamflow at Williamson River below Sprague River, near Chiloquin, Oregon (U.S. Geological Survey streamgage 11502500), water years 1984-2015.

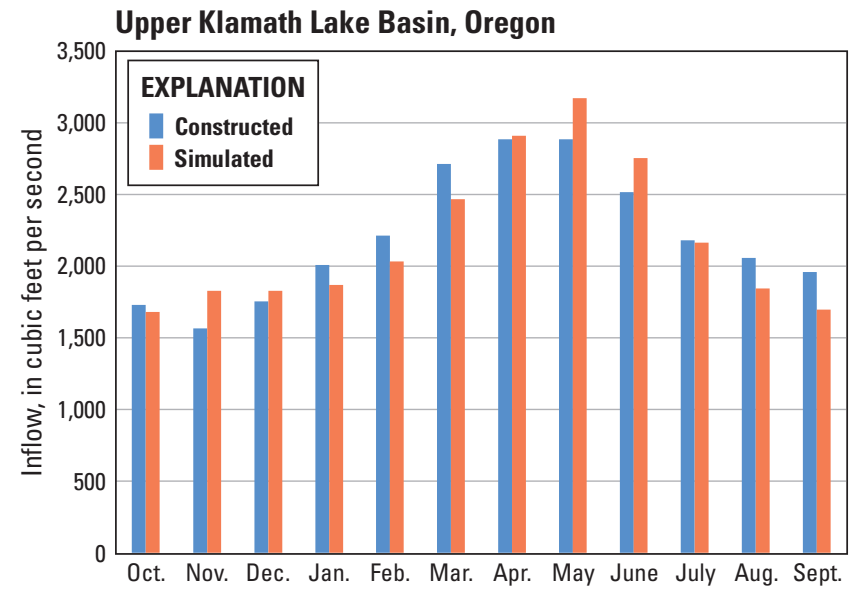

Figure 16. Constructed and simulated mean-monthly inflow to Upper Klamath Lake, Oregon, water years 1984-2015.

Table 8. Adjusted measured and simulated mean-April-September streamflow for the three Precipitation-Runoff Modeling System models for water years 1984-2015.

[In this report, Link River at Klamath Falls (U.S. Geological Survey streamgaging station 11507500) is used interchangeably with Upper Klamath Lake because their drainage areas are nearly identical. Abbreviations: $\mathrm{ft}^{3} / \mathrm{s}$, cubic foot per second; USGS, U.S. Geological Survey]

\begin{tabular}{clrrrr}
\hline $\begin{array}{c}\text { USGS } \\
\text { streamgage } \\
\text { No. }\end{array}$ & \multicolumn{1}{c}{$\begin{array}{c}\text { Basin model } \\
\text { description }\end{array}$} & $\begin{array}{c}\text { Adjusted } \\
\text { measured } \\
\left(\mathbf{f t}^{3} \mathbf{s}\right)\end{array}$ & $\begin{array}{c}\text { Simulated } \\
\left(\mathbf{f t}^{3} \mathbf{s}\right)\end{array}$ & $\begin{array}{c}\text { Difference } \\
\left(\mathbf{f t}^{3} \mathbf{s}\right)\end{array}$ \\
\hline 11501000 & Sprague River near Chiloquin, Oregon & 718 & 710 & 8 \\
11502500 & Williamson River below Sprague River near Chiloquin, Oregon & 1,274 & 1,284 & -10 \\
11507500 & Link River at Klamath Falls, Oregon & 2,416 & 2,442 & -26 \\
\hline
\end{tabular}




\section{Simulated Processes}

In addition to season streamflow forecasting, a reasonably well-calibrated watershed model of the UKL basin provides information on the magnitude and timing of watershed processes, such as evapotranspiration and snowpack, which can be averaged over the entire basin or at specific HRU locations and elevations.

A basic water budget for the UKL basin shows that simulated mean-monthly precipitation peaks in December and is about 21.5 in. annually for WYs 1984-2015 (fig. 17). About 63- and 37-percent of that total leaves the basin through evapotranspiration and runoff, respectively. Both actual evapotranspiration and runoff peak in May.

Although actual evapotranspiration peaks in May, potential evapotranspiration peaks in July (fig. 18). Annually simulated potential and actual evapotranspiration are about 35.8 and 13.6 in., respectively. Milly and Dunne (2002) and Clark and others (2008) discuss varying controls on the supply of available energy and available water in a basin by partitioning precipitation between evaporation and runoff. These controls can be seen in a relation between an index of dryness (potential evapotranspiration/precipitation) and an evaporation ratio (actual evapotranspiration/precipitation). For basins that have an index of dryness of less than 1.0, annual evaporation is constrained by the annual supply of energy. Conversely, for basins that have an index of dryness equal to 1.0 or greater, annual evaporation is constrained by the annual supply of water. Simulated results for the UKL basin for WYs 1984-2015 yield an index of dryness of 1.67 and evaporation ratio of 0.63 , which are ratios indicative of and expected in a semi-arid environment.

Mean-monthly simulated precipitation comprised of rainfall and snowfall in the Upper Klamath Lake basin for water years 1984-2015 is shown in figure 19. For this period, 74 percent of total precipitation for December and January is snowfall. Those 2 months also have the highest and secondhighest precipitation totals. The distribution of snowfall during the year is also directly related to the UKL basin averaged mean-monthly snow-water equivalence (fig. 20). Snowfall from September to January contributes to snowpack accumulation. However, maximum snowpack is always less than the sum of snowfall during these months because of evaporation and sublimation processes. In the future, under global warming, it is anticipated that monthly rainfall will increase in proportion to monthly snowfall and overall annual snowpack will decrease.

\section{Seasonal Streamflow Forecasting}

Using the UKB PRMS model in a real-time seasonal streamflow forecasting application involves several steps. The first requires the creation of daily climate input files based on measured precipitation and air temperature data. These files include a spin-up period (typically 3 years) to the forecast date and can be created using the Draper program (appendix 1). The next step involves using Ensemble Streamflow Prediction (ESP) methods to simulate streamflow from the day the forecast is made to the end of the forecast period using various possible future climate scenarios (Day, 1985) (appendixes 2 and 3). For this project, an ESP feature in the USGS Object User Interface (OUI) software (Markstrom and Koczot, 2008) was used. OUI was first used to parse daily climate data from the 35-year historical record (WYs 1981-2015) into 35 smaller climate input files for the forecast period months (late spring and summer), which are possible future climate scenarios. After creating the smaller input climate input files, OUI then simulated 35 daily streamflow output files using the UKB PRMS model. The final step involved determining which of the simulated outcomes, either a single year or combination of years, would be the most likely representation of expected streamflow conditions during the forecasted months. By reducing the years from the historical record to use in an ESP run, the range of uncertainty in the prediction can be narrowed. Some forecasters use the El Niño Southern Oscillation (ENSO) 3.4 or Pacific Decadal Oscillation (PDO) indexes as criteria for selecting years from the historical record that are similar in climate to the forecasted months. ENSO warm (El Niño) and cold (La Nina) phases are defined by sea-surface temperature anomalies exceeding plus or minus $0.4^{\circ} \mathrm{C}$ in the Niño 3.4 region $\left(5^{\circ} \mathrm{N}-5^{\circ} \mathrm{S}, 120^{\circ}-170^{\circ} \mathrm{W}\right)$ in the Pacific Ocean over specified time periods (Trenberth, 1997). The PDO index is a measure of monthly sea surface temperature anomalies over the North Pacific (poleward of $20^{\circ} \mathrm{N}$ ) (Mantua and others, 1997).

Figure 21 shows an example of ESP using simulated daily inflow to UKL for WY 2015. In the example, the April-September period is being forecasted on April 1, 2015. The period before April 1 was simulated using 2015 daily precipitation and air temperature input to the UKB PRMS model. In the example, climate conditions that will occur from April to September are not yet known. 
Using the ENSO criteria, water year 2015, the example year, was an El Niño year (U. S. National Weather Service, 2018). Other El Niño years within the historical record for 1980-2015 include 1980, 1983, 1987, 1989, 1992, 1995, 1998, 2003, 2007, and 2010 (table 9; fig. 21). Inflow volumes in table 9 and figure 21 were computed from simulated daily inflows to Upper Klamath Lake from April 1 to September 30 using measured daily precipitation and air temperature input data from the El Niño years in the historical record. However, for each of these simulations, an initialization spin-up period was simulated for the 6 years prior to April 1,2015 , to determine antecedent conditions for the model. Measured daily precipitation and air temperature data of that period (April 1, 2009, to March 31, 2015) was used for model input. When the April-September volumes are ranked, their exceedance probabilities, also shown in table 9, are computed as:

$$
\text { Probability Exceedance }(i)=i /(\mathrm{N}+1) \times 100
$$

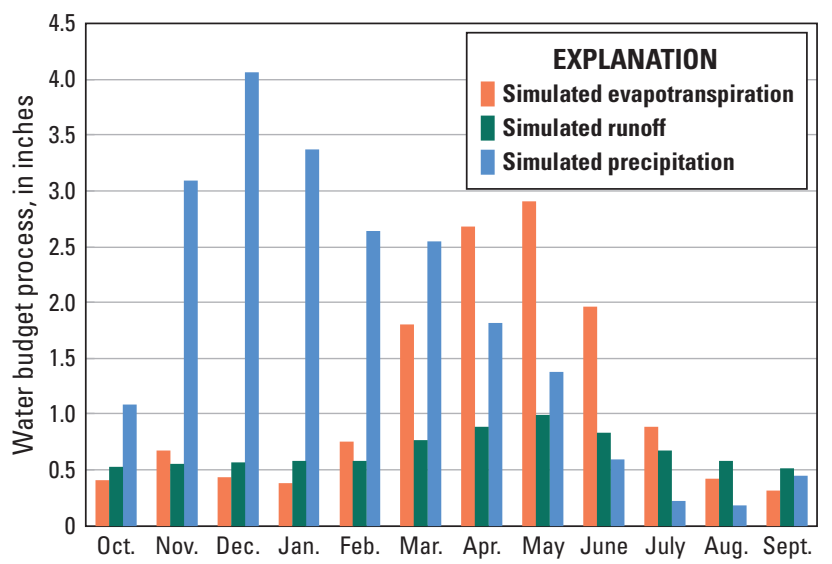

Figure 17. Mean-monthly simulated water-budget in the Upper Klamath Lake Basin, Oregon, water years 1984-2015.

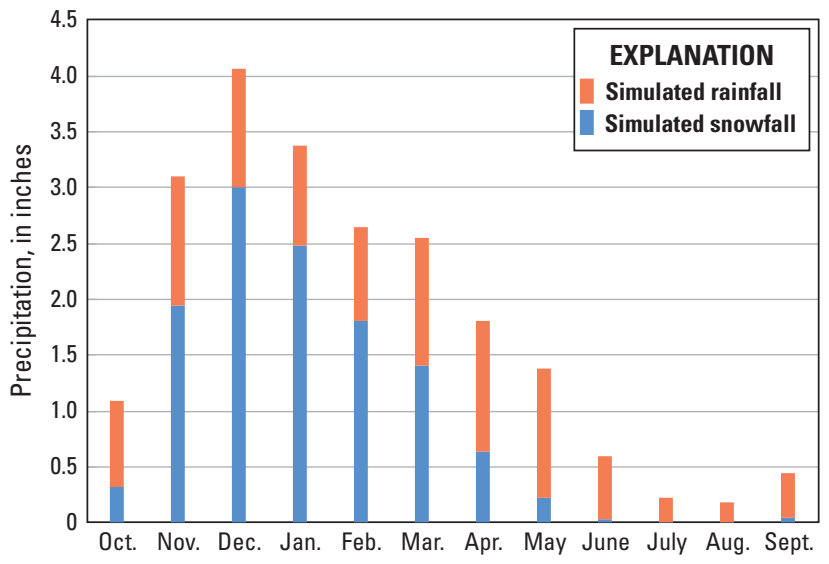

Figure 19. Mean-monthly simulated rainfall and snowfall in the Upper Klamath Lake basin, Oregon, water years 1984-2015. where

$i \quad$ is the historical-trial rank order, in descending volume, and

$N \quad$ is the total number of years in the historical record.

The 50th percent exceedance probability was between 481.9 and 503.0 TAF, which was close to the simulated AprilSeptember volume (482.1 TAF) using measured 2015 climate input data.

The seasonal forecasting of inflows to Upper Klamath Lake (table 9 and fig. 21) for 2015 is an example of how a physical-process-based model can provide seasonal streamflow forecasts for upper Klamath Basin water management, where reliable forecasts are critical for agriculture, power production, and ecosystem health. Although physical-process-based models, like the UKB PRMS model, will not necessarily replace existing statistical multiple regression forecast methods, they can be seen as a viable alternative.

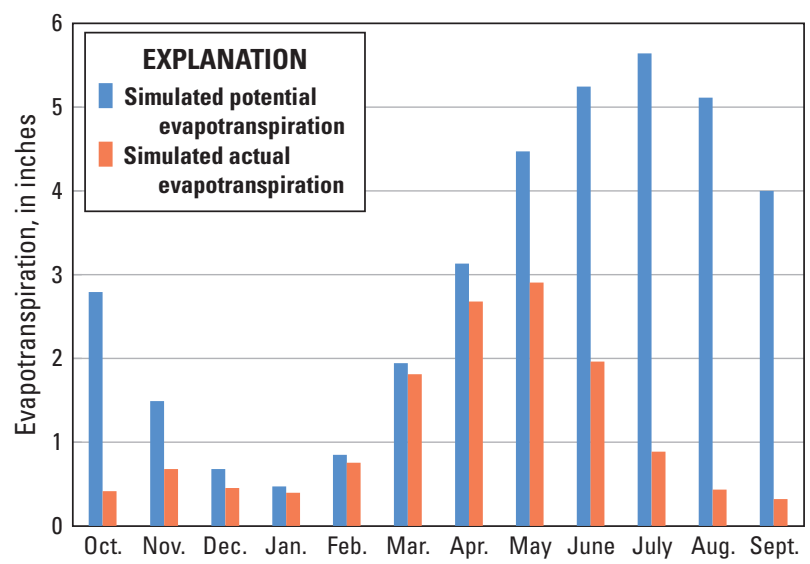

Figure 18. Mean-monthly simulated potential and actual evapotranspiration in the Upper Klamath Lake basin, Oregon, water years 1984-2015. ET, evapotranspiration.

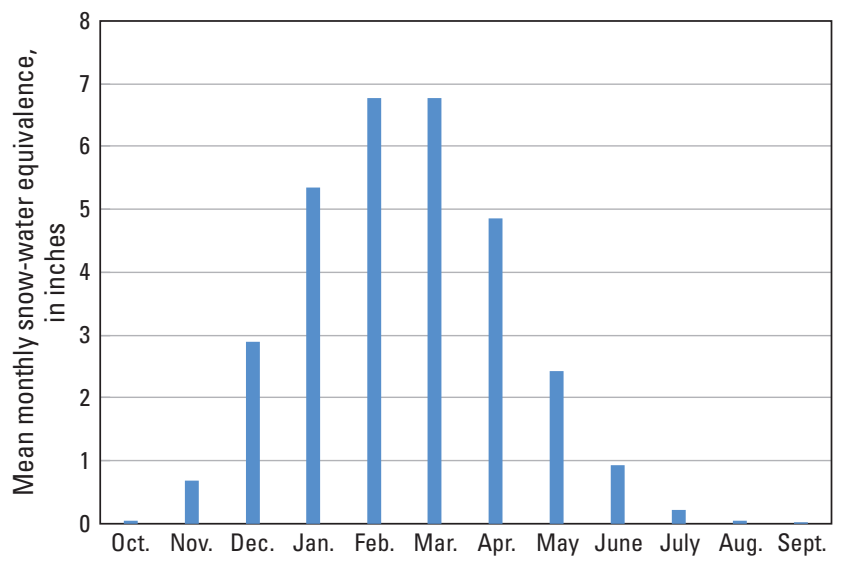

Figure 20. Mean-monthly simulated snow-water equivalence in the Upper Klamath Lake basin, Oregon, water years 1984 to 2015. 


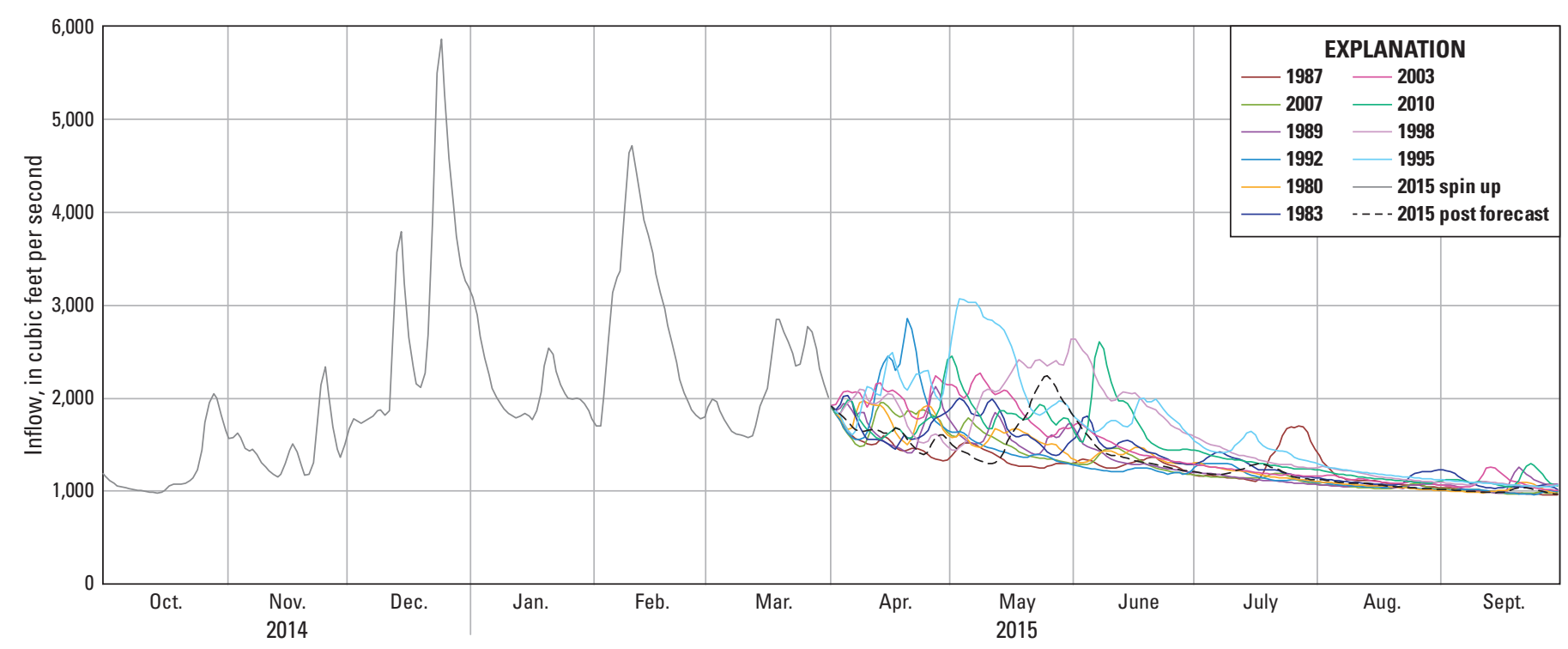

Figure 21. Ensemble Streamflow Prediction (ESP) runs using water year 2015 simulated daily inflow to Upper Klamath Lake, Oregon. The 2015 spin-up period was simulated as part of the ESP forecast and used measured 2015 climate input data up to the date of the April 1 forecast. The 2015 post-forecast period was not part of the ESP forecast. It is shown for comparison.

Table 9. Simulated inflow volumes to the Upper Klamath Lake for April-September 2015 using El Niño Southern Oscillation warm phase climate input data.

[Simulated inflow for 2015 is shown for comparison with the other years used in the forecast example. Abbreviation: TAF, thousand acre feet]

\begin{tabular}{cccc}
\hline $\begin{array}{c}\text { El Niño } \\
\text { years }\end{array}$ & $\begin{array}{c}\text { Simulated } \\
\text { April-September 2015 } \\
\text { volume } \\
\text { (TAF) }\end{array}$ & Rank & $\begin{array}{c}\text { Percent } \\
\text { exceedence } \\
\text { probability }\end{array}$ \\
\hline 1995 & 604.2 & 1 & 9.1 \\
1998 & 579.4 & 2 & 18.2 \\
2010 & 541.5 & 3 & 27.3 \\
2003 & 531.5 & 4 & 36.4 \\
1983 & 503.0 & 5 & 45.5 \\
1980 & 481.9 & 6 & 54.5 \\
1992 & 479.1 & 7 & 63.6 \\
1989 & 477.1 & 8 & 72.7 \\
2007 & 468.7 & 9 & 81.8 \\
1987 & 460.4 & 10 & 90.9 \\
2015 & 482.1 & & \\
\hline
\end{tabular}

\section{Model Limitations}

The UKB PRMS model, like any process-based hydrologic model, is an approximation of physical conditions in the Upper Klamath Basin. Water managers should be mindful of its limitations when using the model or interpreting model output.
The UKB PRMS model uses daily precipitation and air temperature datasets as input to simulate daily streamflow. A common source of error in precipitation-runoff modeling is interpolation techniques used to transfer point meteorological data from a station to locations and elevations away from the station. The meteorological datasets used to calibrate the model in this study were created using the Draper program (Donovan and Koczot, 2019). In this application, the program uses measured data from 32 meteorological stations located within and surrounding the UKB. Often there is measurement error at the stations due to human or equipment reasons. The Draper technique also uses statistical relations between the meteorological station and the HRU, which contains error. For this study, that relationship was derived from 1-km gridded Daymet climate datasets (Thornton and others, 1997; Thornton and others, 2016).

Another limitation with the UKB PRMS model is the resolution of the HRUs in regards to basin surface conditions, flows, and storage fluxes. Although 403 HRUs were used to describe the basin, each HRU is a homogeneous unit, and some of the soil, vegetation, geologic complexities within a single HRU are lost.

PRMS models can be more successfully calibrated if they are used on unregulated basins having minimal humancaused disturbances. Calibrating PRMS for the UKB was more challenging than other PRMS modeling applications because of numerous streamflow withdrawals for irrigation consumptive use throughout the lower elevations in the basin. Before calibrating the models, it was necessary to modify the measured daily streamflow time series by adding net consumptive use losses into the records. However, estimating 
net consumptive use is challenging because of limited available data at all locations in the basin and throughout the modeling period from 1980 to 2015 . After assessing data from different agencies and publications, net consumptive use estimates made for the Upper Klamath Basin Comprehensive Agreement (State of Oregon, 2014) were assumed to be reliable and current, and were used for this study. However, error is still introduced because it is difficult to quantify how consumptive use rates have changed over the modeling period. Even if the number of acres of irrigation was constant during this period, it would still be difficult to accurately quantify the variation in consumptive use from dry years to wet years. For this study, a constant estimate of consumptive use was used.

Calibrating the UKB PRMS model was challenging because a measured historical time series of daily inflow to the lake was unavailable. It was necessary to construct a naturalized streamflow time series using the monthly UKL net inflow time series provided by the BOR. In addition to compensating for estimated inexact consumptive use losses, constructing a UKL inflow time series also involved compensating for precipitation entering the lake and evapotranspiration losses from the lake and surrounding wetlands. The monthly net inflow time series also contains errors related to bathymetric measurement, lake bathymetric changes over time, and lake stage and streamflow measurement.

Unlike a multiple regression model, using a physicalprocess-based based hydrologic model in seasonal streamflow forecasting requires determining a future climate scenario that best represents what might occur during the 6-month (or greater) period after the forecast date (present) up to the end of the forecasted period. This also requires creating and assembling daily precipitation and air temperature time series data for the future period. For short-term streamflow forecasting of a few days or weeks, ESP methods work well (Alfieri and others, 2014). For longer seasonal streamflow forecasting, which can typically be $4-6$ months, ESP methods still work well. However, uncertainty in finding the most likely future climate scenario increases.

Multiple regression and physical-process-based based models are created and calibrated using historical climate data that are assumed to be stationary. However, under global warming, future precipitation and air temperature data used as input to these models will likely be outside of the expected range of the historical record. If total precipitation does remain within the range of the historical record, the snowfall and rainfall portions of total precipitation will decrease and increase, respectively. Under these conditions, streamflow forecasts from either a regression equation or a physicalprocess-based model are extrapolations containing greater uncertainty than forecasts made during the historical period.

\section{Summary}

Water managers and stakeholders in the Upper Klamath River Basin need reliable forecasts of seasonal streamflow for decision making that includes balancing water (1) for threatened Chinook (Oncorhynchus tshawytscha) and coho salmon (Oncorhynchus kisutch) in the lower Klamath River, (2) for irrigation of approximately 240,000 acres in the BOR Project, (3) for maintenance of lake stage needed for water quality and habitat for two endangered sucker species, (4) for habitat in the Lower Klamath and Tule Lake National Wildlife Refuges, and (5) for hydroelectric power production. Forecasts of total inflow to UKL for the period of April through September are needed as early as December. For many years, multiple regression equations that relate snowpack and precipitation to total spring-summer streamflow volume have been used for these forecasts. However, future warming trends could decrease snowpack to levels outside of the historical data set used to create the regression equations, which will introduce greater error in statistical forecasts. Statistical equations also do not adequately reflect complicated surface-water and groundwater flow interactions in the UKB. A basin with substantial groundwater storage can have spring and summer streamflow that is very dependent on antecedent conditions of the previous 1 or 2 years. A year with aboveaverage snowpack will not necessarily translate into aboveaverage streamflow if it follows a drought period. Conversely, the effects of drought conditions in the current year might not impact streamflow if it follows a period of consecutive wet years. Using a physical-process-based based watershed hydrologic model can provide valuable insights into these processes in complicated basins such as the UKB, which are helpful in determining seasonal streamflow forecasts. However, a model is not necessarily a substitute for statistical methods because there are advantages and disadvantages with using both.

The USGS, in cooperation with the U.S. Bureau of Reclamation, completed a study whose objectives included: (1) constructing a physical-process-based watershed hydrologic model covering the UKB drainage basin, (2) calibrating and validating the model for the portion of the UKB draining into UKL using measured streamflow, snowpack, evapotranspiration, and solar radiation data sets, and (3) demonstrate the model's utility for forecasting seasonal streamflow volumes using Ensemble Streamflow Prediction (ESP).

The model used in this study is the PRMS, version 5.0, which is a deterministic, distributed-parameter, physicalprocess-based modeling system developed by the USGS that can simulate daily streamflow at the basin outlet as well as a suite of snow, evapotranspiration, surface-water, and 
groundwater processes within the basin. Daily precipitation and minimum and maximum daily air temperature data are input to the model. Basin surface conditions are defined using spatial units having homogeneous hydrologic and climatic characteristics called hydrologic response units (HRUs). The UKB PRMS model encompasses the drainage area upstream of Iron Gate Dam, California, approximately $8,300 \mathrm{mi}^{2}$, which is discretized into 403 HRUs and 95 stream segments.

Daily precipitation and air temperature time series data were available from 32 NWS and NRCS meteorological stations within and surrounding the UKB. With the exception of Crater Lake, the NWS stations are located near towns, or on farms, and at lower elevations from about 2,700 to 4,800 $\mathrm{ft}$. However, NRCS stations in the UKB are located at higher elevations from about 4,700 to 7,100 ft and usually just below a ridge line, but not on a ridge line. The Draper ClimateDistribution Software was used to create area-weighted averaged interpolated daily precipitation and air temperature time series for all HRUs based on measured data from the meteorological stations.

Prior to beginning the calibration procedure, it was necessary to adjust the measured daily streamflow records to account for irrigation consumptive-use losses. This was done by adding net consumptive use in the basins into the streamflow records to make them more closely resemble the natural flow.

The model uses a parameter file that defines the physical and climatic conditions of the basin. During the model calibration, adjustments are made to many of the parameter values for the purpose of minimizing error between simulated and measured daily streamflow data. A model calibration and validation period from WYs 2000-15 and 1984-99, respectively, was used in the study. PRMS parameters that characterize basin physical characteristics were directly or indirectly determined from geospatial data sets containing vegetation, soils, geology, topography information. These parameters did not need to be adjusted for model calibration because they are constant during the simulation period. Before calibrating the model using streamflow data, mean-monthly solar radiation data from the National Renewable Energy Laboratory (NREL) was used to calibrate solar radiation PRMS parameters. Then mean-monthly evaporation data from the National Oceanic and Atmospheric Administration was used to calibrate potential evapotranspiration PRMS parameters.

LUCA, an automated parameter-optimization program, was used to calibrate PRMS runoff and snow-related parameters. The program performs a multiple-objective, stepwise calibration of parameters, and was used for the Sprague River, Williamson River, and UKL basin model calibrations. The Wood River basin models did not have sufficient long-term measured daily streamflow records that are necessary for parameter optimization. The LUCA optimization runs for the Sprague River, Williamson River, and UKL basin models used the same period of WYs 2000-15.
Measured snow-water equivalence data sets were also used in the model calibration. While it was important to calibrate the model for both SWE and streamflow, a greater priority was given to streamflow because SWE data has more error and because streamflow volume is the forecasting objective of the study. Available measured daily SWE data sets included SNOTEL data from higher elevations and SNODAS data averaged for the entire UKB.

The calibrated Sprague River, Williamson River, and UKL basin models were evaluated with performance statistics and visually with plots that compared measured and simulated daily streamflow for the calibration and validation periods, WYs 2000-15 and 1984-99, respectively. The performance statistics included percent bias, percent relative error, and root-mean-square error. Statistics were computed annually, monthly, for October-March, and for April-September. Because the models were created for seasonal streamflow forecasting in the spring and summer, it was important to have a satisfactory calibration for April-September. With the exception of the October-March period, percent Bias statistics were all within plus or minus 5-percent for the calibration and validation periods.

Using the UKB PRMS model in real-time seasonal streamflow forecasting involves several steps. First daily climate input files based on measured precipitation and air temperature data need to be created for the simulation period up to the forecast date. The next step involves using Ensemble Streamflow Prediction methods that run the PRMS model and simulate streamflow from the forecast date (present) to the last day in the forecasted period using a range of possible future climate scenarios. Exceedance probabilities are then computed from the simulated output of many scenarios.

The UKB PRMS model was used to forecast the volume of inflow to Upper Klamath Lake for a 6-month period from April 1, 2015, to September 30, 2015, using a range of climate data sets based on El Niño Southern Oscillation (ENSO) criteria. Because 2015 was a warm-phase ENSO period, climate data for 10 warm phase ENSO years from 1980 to 2010 were used as input to the model. The simulated April to September 2015 UKL inflow volume based on measured 2015 climate data was 482.1 thousand acre-feet, which was very close to the 50th percent exceedance probability computed from the 10 simulated scenarios that used warm-phase ENSO climate input data from 1980 to 2010.

Limitations to the UKB PRMS model included error in the precipitation and air temperature time series data that are input to the model. In addition to human or equipmentrelated measurement error at the meteorological sites, a common source of error with many precipitation-runoff models are interpolation techniques used to transfer data from a meteorological station to locations that are at different elevations and not near the station. Another limitation with the UKB PRMS model was the unnatural quality of the measured daily streamflow records used in calibration. Model calibration is more successful with natural streamflow records because the model was designed to simulate natural conditions. 
Before calibrating the models, it was necessary to modify, or naturalize, the measured streamflow time series by adding net consumptive use losses from to irrigation into the records. However, consumptive use estimates contain error due to limited available data used for making the estimation. Also, consumptive use losses were not constant in the historical record and varied from year to year.

A possible future phase of this study would be to construct a fully coupled surface-water and groundwater model for the UKB using the GSFLOW model. A fully developed GSFLOW model for the UKB could potentially be used for both seasonal streamflow forecasting and various water management applications that include groundwater pumping.

\section{Acknowledgments}

The author gratefully thanks David Felstul, Bureau of Reclamation, Klamath Falls, Oregon, for providing support for this project. The author also thanks Kathryn Koczot, U.S. Geological Survey California Water Science Center, for her assistance with climate-data interpolation and ensemble streamflow prediction software programs.

\section{References Cited}

Alfieri, L., Pappenberger, F., Wetterhall, F., Haiden, T., Richardson, D., and Salamon, P., 2014, 2014, Evaluation of ensemble streamflow predictions in Europe: Amsterdam, Journal of Hydrology, v. 517, p. 913-922, accessed March 30, 2019, at https://doi.org/10.1016/j.jhydrol.2014.06.035.

Blodgett, D.L., Booth, N.L., Kunicki, T.C., Walker, J.L., and Viger, R.J., 2011, Description and testing of the Geo Data Portal-Data integration framework and Web processing services for environmental science collaboration: U.S. Geological Survey Open-File Report 2011-1157, 9 p., accessed September 30, 2017, at https://pubs.usgs.gov/ of $/ 2011 / 1157 /$.

Bureau of Reclamation, 2018, Project history: Bureau of Reclamation, accessed April 12, 2018, at https://www.usbr. gov/mp/kbao/aboutus/index.html.

Clark, M.P., Slater, A.G., Rupp, D.E., Woods, R.A., Vrugt, J.A., Gupta, H.V., Wagener, T., and Hay, L.E., 2008, Framework for understanding structural errors (FUSE) - A modular framework to diagnose differences between hydrological models: Water Resources Research, v. 44, no. 12, W00B02, accessed March 30, 2019, at https://doi. org/10.1029/2007WR006735.
Day, G.N., 1985, Extended streamflow forecasting using NWSRFS-American Society of Civil Engineers: Journal of Water Resources Planning and Management, v. 111, no. 2, p. 157-170, accessed March 30, 2019, at https://doi. org/10.1061/(ASCE)0733-9496(1985)111:2(157).

Dicken, S.N., and Dicken, E.F., 1985, The legacy of ancient Lake Modoc-A historical geography of the Klamath Lakes Basin, Oregon and California: Eugene, University of Oregon, 165 p., accessed March 30, 2019 at https://www. oregon.gov/OPRD/HCD/OHC/docs/klamath_klamathbasin context.pdf.

Donovan, J.M., and Koczot, K.M., 2019, User's manual for the Draper Climate-Distribution Software Suite with dataevaluation tools: U.S. Geological Survey Techniques and Methods 7-C22, 55 p., accessed March 30, 2019, at https:// pubs.er.usgs.gov/publication/tm7C22.

Duan, Q.Y., Gupta, V.K., and Sorooshian, Soroosh, 1993, Shuffled complex evolution approach for effective and efficient global minimization: Journal of Optimization Theory and Applications, v. 76, no. 3, p. 501-521, accessed March 30, 2019, at https://doi.org/10.1007/BF00939380.

Farnsworth, R.K., and Thompson, E.S., 1982, Mean monthly, seasonal, and annual pan evaporation for the United States: Washington, D.C., National Oceanic and Atmospheric Administration Technical Report NWS 34, 82 p., accessed March 30, 2019, at https://www.nws.noaa.gov/oh/hdsc/ Technical_reports/TR34.pdf.

Farnsworth, R.K., Thompson, E.S., and Peck, E.L., 1982, Evaporation atlas for the contiguous 48 United States: Washington, D.C., National Oceanic and Atmospheric Administration Technical Report NWS 33, 41 p., accessed March 30, 2019, at https://www.nws.noaa.gov/oh/hdsc/ Technical_reports/TR33.pdf.

Gannett, M.W., Lite, K.E., Jr., La Marche, J.L., Fisher, B.J., and Polette, D.J., 2007, Ground-water hydrology of the upper Klamath Basin, Oregon and California: U.S. Geological Survey Scientific Investigations Report 2007-5050, 84 p., accessed March 30, 2019, at https://doi. org/10.3133/sir20075050.

Gannett, M.W., Wagner, B.J., and Lite, K.E., Jr., 2012, Groundwater simulation and management models for the upper Klamath Basin, Oregon and California: U.S. Geological Survey Scientific Investigations Report 2012-5062, 92 p., accessed March 30, 2019, at https://doi. org/10.3133/sir20125062.

Gonthier, J.B., 1984, A description of aquifer units in eastern Oregon: U.S. Geological Survey Water-Resources Investigations Report 84-4095, p. 14-17., accessed March 30, 2019, at https://pubs.er.usgs.gov/publication/wri844095. 
Harbaugh, A.W., 2005, MODFLOW-2005-The U.S. Geological Survey modular ground-water model-the Ground-Water Flow Process: U.S. Geological Survey Techniques and Methods 6-A16, variously paginated., accessed March 30, 2019, at https:/pubs.usgs.gov/tm/2005/ tm6A16/.

Hay, L.E., and Umemoto, Makiko, 2006, Multiple-objective stepwise calibration using Luca: U.S. Geological Survey Open-File Report 2006-1323, 25 p., accessed March 30, 2019, at http://pubs.usgs.gov/of/2006/1323/.

Hay, L.E., McCabe, G.J., Clark, M.P., and Risley, J.C., 2009, Reducing streamflow forecast uncertainty-Application and qualitative assessment of the Upper Klamath River basin, Oregon: Journal of the American Water Resources Association, v. 45, no. 3, p. 580-596, DOI: 10.1111/j.17521688.2009.00307, p. 580-596., accessed March 30, 2019, at https://onlinelibrary.wiley.com/doi/10.1111/j.17521688.2009.00307.x.

Hubbard, L.H., 1970, Water budget of Upper Klamath Lake, southwestern Oregon: U.S. Geological Survey Hydrologic Investigations Atlas HA-351, 1 sheet, scale 1:250,000, accessed March 30, 2019, at https://pubs.er.usgs.gov/ publication/ha351.

Jensen, M.E., and Haise, H.R., 1963, Estimating evapotranspiration from solar radiation: Journal of the Irrigation and Drainage Division, American Society of Civil Engineers: v. 89, p. 15-44., accessed March 30, 2019, at https://cedb.asce.org/CEDBsearch/record. jsp?dockey $=0012944$.

Koczot, K.M., Jeton, A.E., McGurk, B.J., and Dettinger, M.D., 2005, Precipitation-runoff processes in the Feather River Basin, northeastern California, with prospects for streamflow predictability, water years 1971-97: U.S. Geological Survey Scientific Investigations Report 20045202, 82 p., accessed March 30, 2019, at https://pubs.usgs. gov/sir/2004/5202/.

Leavesley, G.H., Lichty, R.W., Troutman, B.M., and Saindon, L.G., 1983, Precipitation-runoff modeling systemUser's manual: U.S. Geological Survey Water-Resources Investigations Report 83-4238, 48 p., accessed March 30, 2019, at https://pubs.er.usgs.gov/publication/wri834238.

Mantua, N.J., Hare, S.R., Zhang, Y., Wallace, J.M., and Francis, R.C., 1997, 1997, A Pacific interdecadal climate oscillation with impacts on salmon production: Bulletin of the American Meteorological Society, v. 78, no. 6, p. 1069-1079, accessed March 30, 2019, https://doi. org/10.1175/1520-0477(1997)078<1069:APICOW >2.0 .CO;2.
Markstrom, S.L., and Koczot, K.M., 2008, User's manual for the object user interface (OUI)_-An environmental resource modeling framework: U.S. Geological Survey Open-File Report 2008-1120, 39 p., accessed March 30, 2019, at https://pubs.usgs.gov/of/2008/1120/.

Markstrom, S.L., Hay, L.E., and Clark, M.P., 2016, 2016, Towards simplification of hydrologic modelingIdentification of dominant processes: Hydrology and Earth System Sciences, v. 20, no. 11, p. 4655-4671, accessed March 30, 2019, at https://doi.org/10.5194/hess-20-46552016.

Markstrom, S.L., Hay, L.E., Ward-Garrison, C.D., Risley, J.C., Battaglin, W.A., Bjerklie, D.M., Chase, K.J., Christiansen, D.E., Dudley, R.W., Hunt, R.J., Koczot, K.M., Mastin, M.C., Regan, R.S., Viger, R.J., Vining, K.C., and Walker, J.F., 2012, Integrated watershed-scale response to climate change for selected basins across the United States: U.S. Geological Survey Scientific Investigations Report 2011-5077, 143 p., accessed March 30, 2019, https://doi. org/10.3133/sir20115077.

Markstrom, S.L., Niswonger, R.G., Regan, R.S., Prudic, D.E., and Barlow, P.M., 2008, GSFLOW-Coupled ground-water and surface-water flow model based on the integration of the Precipitation-Runoff Modeling System (PRMS) and the Modular Ground-Water Flow Model (MODFLOW-2005): U.S. Geological Survey Techniques and Methods 6-D1, 240 p., accessed March 30, 2019, at https://pubs.usgs.gov/ $\mathrm{tm} / \mathrm{tm} 6 \mathrm{~d} 1 /$.

Markstrom, S.L., Regan, R.S., Hay, L.E., Viger, R.J., Webb, R.M.T., Payn, R.A., and LaFontaine, J.H., 2015, PRMS-IV - The precipitation-runoff modeling system (version 4): U.S. Geological Survey Techniques and Methods, book 6, chap. B7, 158 p., accessed March 30, 2019, at http://dx.doi.org/10.3133/tm6B7.

Milly, P.C.D., and Dunne, K.A., 2002, Macroscale water fluxes 2-Water and energy supply control of their interannual variability: Water Resources Research, v. 38, no. 10, p. 1206, accessed March 30, 2019, at https://doi. org/10.1029/2001WR000760.

National Oceanic and Atmospheric Administration, 2019, Climate data online search: National Oceanic and Atmospheric Administration website, accessed May 13, 2018, at https://www.ncdc.noaa.gov/cdo-web/search.

National Operational Hydrologic Remote Sensing Center, 2004, Snow data assimilation system (SNODAS) data products at NSIDC, 2004-2014: Boulder, Colorado, National Snow and Ice Data Center, accessed September 2015, at http://dx.doi.org/10.7265/N5TB14TC. 
National Renewable Energy Laboratory, 1992, National solar radiation data base user's manual (1961-1990): National Renewable Energy Laboratory, accessed May 7, 2018, at http://rredc.nrel.gov/solar/pubs/NSRDB/.

Natural Resource Conservation Service, 2018, Description of STATSGO2 database: Natural Resources Conservation Service, United States Department of Agriculture, accessed May 9, 2018, at https://www.nrcs.usda.gov/wps/portal/nrcs/ detail/soils/survey/geo/?cid=nrcs142p2_053629.

Natural Resources Conservation Service, 2019, SNOTEL historic data: Natural Resources Conservation Service website, accessed May 13, 2018, at https://wcc.sc.egov. usda.gov/nwcc/tabget.

Oregon Water Resources Department, 2018, Drought annex state of Oregon emergency operations plan: Oregon Water Resources Department, accessed March 30, 2019, at https:// www.oregon.gov/owrd/WRDPublications1/2016ORDrough tAnnex.pdf

PRISM Climate Group, 2018, PRISM climate data: PRISM Climate Group, accessed May 8, 2018, at http://prism. oregonstate.edu.

Regan, R.S., and LaFontaine, J.H., 2017, Documentation of the dynamic parameter, water-use, stream and lake flow routing, and two summary output modules and updates to surface-depression storage simulation and initial conditions specification options with the precipitation-runoff modeling system (PRMS): U.S. Geological Survey Techniques and Methods, book 6, chap. B8, 72 p., accessed September 30, 2017, at http://dx.doi.org/10.3133/tm6B8.

Regan, R.S., Markstrom, S.L., Hay, L.E., Viger, R.J., Norton, P.A., Driscoll, J.M., and LaFontaine, J.H., 2018, Description of the National Hydrologic Model for use with the Precipitation-Runoff Modeling System (PRMS): U.S. Geological Survey Techniques and Methods, book 6, chap B9, 38 p., accessed March 30, 2019, at https://doi. org/10.3133/tm6B9.

Risley, J.C., Gannett, M.W., Lea, J.K., and Roehl, E.A., Jr., 2005, An analysis of statistical methods for seasonal flow forecasting in the Upper Klamath River Basin of Oregon and California: U.S. Geological Survey Scientific Investigations Report 2005-5177, 44 p., accessed March 30, 2019, at https://doi.org/10.3133/sir20055177.

Risley, J.C., and Hay, L.E., 2006, Evaluation of ensemble streamflow prediction forecasts for the Upper Klamath River basin conditioned on climate indicators in the Upper Klamath basin, Oregon and California: Proceedings to the 3rd Federal Interagency Hydrologic Modeling Conference, Reno, Nevada, 8 p., accessed March 30, 2019, at https://acwi.gov/hydrology/mtsconfwkshops/conf proceedings/3rdFIHMC/third_fihmc_nevada-2006.pdf.
Risley, J.C., Hay, L.E., and Markstrom, S.L., 2012, Watershed scale response to climate change-Sprague River Basin, Oregon: U.S. Geological Survey Fact Sheet 2011-3120, 6 p., accessed March 30, 2019, at https://doi.org/10.3133/ fs20113120.

Rosenberg, E.A., Wood, A.W., and Steinemann, A.C., 2011, Statistical applications of physically based hydrologic models to seasonal streamflow forecasts: Water Resources Research, v. 47, no. 3, W00H14, accessed March 30, 2019, at https://doi.org/10.1029/2010WR010101.

State of Oregon, 2014, Proposed Upper Klamath Basin agreement, exhibits, summary, and media release: State of Oregon, accessed May 16, 2018, at http://www.oregon.gov/ gov/policy/environment/taskforce/Pages/Proposed_Upper_ Klamath_Basin.aspx.

Taylor, G.H., and Hannan, C., 1999, The climate of OregonFrom rain forest to desert: Corvallis, Oregon State University Press, 224 p., accessed March 30, 2019, at http:// osupress.oregonstate.edu/book/climate-of-oregon.

Thornton, P.E., Running, S.W., and White, M.A., 1997, Generating surfaces of daily meteorology variables over large regions of complex terrain: Journal of Hydrology, v. 190, no. 3-4, p. 214-251, accessed March 30, 2019, at https://doi.org/10.1016/S0022-1694(96)03128-9.

Thornton, P.E., Thornton, M.M., Mayer, B.W., Wei, Y., Devarakonda, R., Vose, R.S., and Cook, R.B., 2016, DAYMET - Daily surface weather data on a 1-km grid for North America, Version 3: Oak Ridge, Tennessee, Oak Ridge National Laboratory, Distributed Active Archive Center dataset, accessed September 14, 2015, at https:// dx.doi.org/10.3334/ORNLDAAC/1328.

Trenberth, K.E., 1997, The definition of El Niño: Bulletin of the American Meteorological Society, v. 78, no. 12, p. 2771-2777, accessed March 30, 2019, at https://doi. org/10.1175/1520-0477(1997)078<2771:TDOENO $>2.0$ .CO;2.

U.S. Bureau of Reclamation, 2018, Klamath Basin Area Office: U.S. Bureau of Reclamation, accessed May 7, 2018, at https://www.usbr.gov/mp/kbao/aboutus/index.html.

U.S. Geological Survey, 2019a, Downsizer: U.S. Geological Survey website, accessed May 13, 2018, at https://wwwbrr. cr.usgs.gov/projects/SW_MoWS/Downsizer.html.

U.S. Geological Survey, 2019b, Geo data portal: U.S. Geological Survey website accessed May 14, 2018, at https://cida.usgs.gov/gdp/. 
U.S. Geological Survey, 2019c, GIS features of the geospatial fabric for national hydrologic modeling: U.S. Geological Survey ScienceBase-Catalog, accessed February 2017 at https://www.sciencebase.gov/catalog/ item/535eda80e4b08e65d60fc834.

U.S. Geological Survey, 2019d, Modeling of watershed systems: U.S. Geological Survey website, accessed May 28, 2018, at https://wwwbrr.cr.usgs.gov/projects/SW_MoWS/.

U.S. Geological Survey, 2019e, USGS national elevation dataset (NED): U.S. General Services Administration, Technology Transformation Service, Data.gov, accessed July 2019 at https://catalog.data.gov/dataset/usgs-nationalelevation-dataset-ned.
U.S. National Weather Service, 2018, Cold \& warm episodes by season: Climate Prediction Center website, accessed May 31, 2018, at http://origin.cpc.ncep.noaa.gov/products/ analysis_monitoring/ensostuff/ONI_v5.php.

Wilcox, S., 2012, National solar radiation database 1991-2010 update-Users's manual: National Renewable Energy Laboratory, NREL report no. TP-5500-54824, 479 p., accessed March 30, 2019, at https:/www.nrel.gov/docs/ fy12osti/54824.pdf.

Viger, R.J., 2014, Preliminary spatial parameters for PRMS based on the geospatial fabric, NLCD2001 and SSURGO: U.S. Geological Survey data release, accessed September 16, 2016, at http://dx.doi.org/doi:10.5066/F7WM1BF7.

Viger, R.J., and Bock, A., 2014, GIS features of the geospatial fabric for national hydrologic modeling: U.S. Geological Survey, accessed March 30, 2019, at http://dx.doi.org/ doi:10.5066/F7542KMD. 


\section{Appendix 1. Creating Climate Input Files for the Upper Klamath Basin Precipitation-Runoff Modeling System Model}

Daily precipitation and minimum and maximum air temperature files to run the Upper Klamath Basin PRMS model were created using Draper Climate-Distribution software (Donovan and Koczot, 2019). Complete instructions for using the software are provided in that publication. However, this appendix contains additional information to facilitate the creation of the climate input files for a real-time PRMS streamflow forecasting application.

(1) Create three files containing measured data from the observation stations:

The files must use the following names and directory structure:

./KLAMATH/PPT/KLAMATH_MEAS_PPT.data

.KLAMATH/TMAX/KLAMAT̄H_MEAS_TMAX.data

./KLAMATH/TMIN/KLAMATH_MEAS_TMIN.data

The number of data columns (32) and their ordering must be identical to the stations in table 3 . These three files can be created by simply copying and extending the calibration version of these files (January 1, 1980, to December 31, 2015) from January 1, 2016, up to the date when the forecast is made (present).

For the National Weather Service Cooperative Observer Network (COOP) stations, data can be retrieved at National Oceanic and Atmospheric Administration (2019).

A faster alternative is retrieving NWS COOP data using the USGS Downsizer software, which can be downloaded U.S. Geological Survey (2019a). However, Natural Resources Conservation Services snow telemetry data cannot be retrieved using the downsizer. The data can be downloaded at Natural Resources Conservation Service (2019).

(2) Get the normalization file from the project archive:

This file contains the same starting and ending dates that were used for calibration (January 1, 1980, to December $31,2015)$. This is not the same period of the measured data files, which are longer because they extend up to the forecast date. The normalization file must use the following name and directory structure:
./KLAMATH/KLAMATH_NORM_POR

(3) Get the file containing the latitudes and longitudes of all HRU centroids from the project archive:

The file needs to have the following name and directory structure:

.KLAMATH/KLAMATH CENTROIDS

(4) These additional files from the project archive are needed in the PPT, TMAX, and TMIN directories:

.KLAMATH/PPT/KLAMATH PPT STA AVERAGES

.KLAMATH/PPT/KLAMATH_PPT_RANGE

.KLAMATH/PPT/KLAMATH_PPT_LOCATIONS

.KLAMATH/PPT/KLAMATH_PPT_AVERAGES

./KLAMATH/PPT/GR_DIAG_PPT/diag.grs

./KLAMATH/PPT/GR_DIAG_PPT/view_diag_in_gr.bat .KLAMATH/TMAX/

KLAMATH_TMAX_STA_AVERAGES

.KLAMATH/TMAX/KLAMATH_TMAX_RANGE

./KLAMATH/TMAX/KLAMATH

TMAX LOCATIONS

./KLAMATH/TMAX/KLAMATH_TMAX_AVERAGES .KLAMATH/TMAX/

KLAMATH_TMAX_STA_PRISM_SIGMA

.KLAMATH/TMAX/

KLAMATH_TMAX_PRISM_SIGMA

./KLAMATH/TMAX/GR_DIAG_TMAX/diag.grs

./KLAMATH/TMAX/GR_DIAG_TMAX/

view_diag_in_gr.bat

.KLAMATH/TMIN/KLAMATH

TMIN_STA_AVERAGES

./KLAMATH/TMIN/KLAMATH_TMIN_RANGE

.KLAMATH/TMIN/KLAMATH_TMIN_LOCATIONS

.KLAMATH/TMIN/KLAMATH_TMIN_AVERAGES

.KLAMATH/TMIN/

KLAMATH_TMIN_STA_PRISM_SIGMA

.KLAMATH/TMIN/

KLAMATH_TMIN_PRISM_SIGMA

./KLAMATH/TMIN/GR_DIAG_TMIN/diag.grs

.KLAMATH/TMIN/GR_DIAG_TMIN/

view_diag_in_gr.bat 
All of these files were previously created for the model calibration and do not need to be recreated for a real-time streamflow forecasting application.

(5) Running Draper software:

The executable needs to be placed at the level just above the KLAMATH folder:

draper.exe/KLAMATH/

a. Click on: draper.exe

b. Enter when prompted for the basin name: KLAMATH

c. Enter when prompted for the name of the sub-folder: PPT

d. Repeat steps $\mathrm{a}, \mathrm{b}$, and $\mathrm{c}$ for TMAX and TMIN

(6) The Draper output files include:

./KLAMATH/PPT/KLAMATH_DRAPER_PPT.data

.KLAMATH/PPT/KLAMATH_PPT_DRAPER_DIAG. $\operatorname{csv}$

./KLAMATH/PPT/KLAMATH_PPT_DRAPER_LOG

.KLAMATH/PPT/KLAMATH_PPT_STA_DIFFS
.KLAMATH/TMAX/KLAMATH_DRAPER_TMAX. data

.KLAMATH/TMAX/KLAMATH_TMAX_DRAPER_ DIAG.csV

.KLAMATH/TMAX/

KLAMATH_TMAX_DRAPER_LOG

./KLAMATH/TMAX/KLAMATH_TMAX_STA_DIFFS

.KLAMATH/TMIN/KLAMATH_DRAPER_TMIN.data

./KLAMATH/TMIN/KLAMATH_TMIN_DRAPER_ DIAG.csv

.KLAMATH/TMIN/

KLAMATH_TMIN_DRAPER_LOG

.KLAMATH/TMIN/KLAMATH_TMIN_STA_DIFFS

(7) The climate data files formatted and ready to use as input to PRMS are:

./KLAMATH/PPT/KLAMATH_DRAPER_PPT.data ./KLAMATH/TMAX/KLAMATH_DRAPER_TMAX. data

.KLAMATH/TMIN/KLAMATH_DRAPER_TMIN.data 


\section{Appendix 2. Running the Upper Klamath Basin Precipitation-Runoff Modeling System Model}

Complete details on using PRMS modeling software is beyond the scope of this report. It is assumed that the forecaster has prior knowledge or experience with using PRMS. However, information on the PRMS version used in this study is available in Markstrom and others (2015) and Regan and LaFontaine (2017).

The following describes the PRMS file names and file paths:

PRMS executable file:

./prms_work/bin/prms.exe

PRMS control file:

./prms_work/control/Klam_PRMS.control

DRAPER climate input files:

./prms_work/input/Klam_DRAPER_PPT.data

./prms_work/input/Klam_DRAPER_TMAX.data

./prms_work/input/Klam_DRAPER_TMIN.data

Measured streamflow data file:

./prms_work/input/Klam.flow.data

PRMS parameter input file:

./prms_work/input/Klam.K16.forecast.param

PRMS output files:

./prms_work/output/

To start the UKB PRMS model, click on the prms_gui .bat file located in the level just above "/prms_work."

./prms_gui.bat

Table 2-1 identifies the model stream segment outflow index numbers for various basins within the Upper Klamath Basin. Simulated daily streamflow for the drainage areas upstream of these gages can be sent to the PRMS statvar.dat output using the seg_outflow variable and index numbers shown in the table. However, the calibrations discussed in this report only apply to the Sprague River near Chiloquin (11501000), Williamson River below Sprague River near Chiloquin (11502500), and Link River at Klamath Falls (11507500). In this report, the 11507500 Link River at Klamath Falls drainage area is taken to represent the Upper Klamath Lake drainage area.
Table 2-1. Precipitation-Runoff Modeling System stream segment outflow index numbers for various basins within the Upper Klamath Basin.

[In this report, the Link River at Klamath Falls (U.S. Geological Survey streamgage 11507500) drainage area is synonymous with the Upper Klamath Lake drainage area USGS, U.S. Geological Survey]

\begin{tabular}{|c|c|c|}
\hline $\begin{array}{l}\text { USGS } \\
\text { station no. }\end{array}$ & Description & $\begin{array}{c}\text { Model } \\
\text { segment } \\
\text { outflow } \\
\text { index } \\
\text { number }\end{array}$ \\
\hline 11491400 & $\begin{array}{l}\text { Williamson River below Sheep Creek near } \\
\text { Lenz, Oregon }\end{array}$ & 35 \\
\hline 11492400 & $\begin{array}{l}\text { Big Springs Cr below Lenz Ranch near Lenz, } \\
\text { Oregon }\end{array}$ & 47 \\
\hline 11493500 & $\begin{array}{l}\text { Williamson River near Klamath Agency, } \\
\text { Oregon }\end{array}$ & 40 \\
\hline 11495800 & $\begin{array}{l}\text { N Fk Sprague River at Power Plant, near Bly, } \\
\text { Oregon }\end{array}$ & 61 \\
\hline 11497500 & Sprague River near Beatty, Oregon & 55 \\
\hline 11499100 & $\begin{array}{l}\text { Sycan River below Snake Cr near Beatty, } \\
\text { Oregon }\end{array}$ & 63 \\
\hline 11501000 & Sprague River near Chiloquin, Oregon & 51 \\
\hline 11502500 & $\begin{array}{l}\text { Williamson River below Sprague River near } \\
\text { Chiloquin, Oregon }\end{array}$ & 50 \\
\hline 11502940 & Wood River at Dixon Rd near Fort Klamath & 94 \\
\hline 11504115 & Wood River near Klamath Agency, Oregon & 89 \\
\hline 11507500 & Link River at Klamath Falls, Oregon & 18 \\
\hline 11509500 & Klamath River at Keno, Oregon & 21 \\
\hline 11510000 & Spencer Cr near Keno, Oregon & 93 \\
\hline 11510700 & $\begin{array}{l}\text { Klamath River below John Cr Boyle PP near } \\
\text { Keno, Oregon }\end{array}$ & 2 \\
\hline 11516530 & $\begin{array}{l}\text { Klamath River below Iron Gate Dam, Cali- } \\
\text { fornia. }\end{array}$ & 4 \\
\hline
\end{tabular}




\section{Appendix 3. Real-Time Seasonal Forecasting with the Upper Klamath Basin Precipitation-Runoff Modeling System Model}

Using the UKB PRMS model in a real-time forecasting involves several steps.

(1) Create DRAPER PPT, TMAX, and TMIN climate input files:

This first step described in appendix 1 requires extending the daily precipitation, minimum air temperature, and maximum air temperature files up to the day when the forecast is being made. For example, let us suppose we want to make a forecast on March 1, 2018, for the 7-month period from March 1,2018 , to September 30, 2018. The KLAMATH DRAPER PPT.data file should contain daily precipitation (derived from measured data) for every HRU from October 1, 1980, to February 28, 2018.

(2) Manually extend the DRAPER climate and streamflow data files into the future forecast period:

Manually extend the three new DRAPER PPT, TMAX, and TMIN files for the period after the forecast date to the end of the forecast period using dummy data. In the example above, this would be from March 1, 2018, to September 30, 2018.

Manually extend the Klam.flow.data streamflow data file with measured streamflow data up to the date when the forecast will be made. In the example, this would be up to February 28, 2018. Then manually extend the Klam.flow. data file with dummy streamflow data for the period after the forecast date to the end of the forecast period. In the example, this would be from March 1, 2018, to September 30, 2018.

These files must use the following names and file locations:

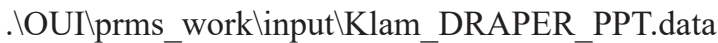

. OUI 1 prms_worklinput Klam_DRAPER_TMAX.data

. IOUI/prms_worklinputKKlam_DRAPER_TMIN.data

.OUI $p$ prms_worklinput|Klam.flow.data

(3) Parse historical climate and streamflow files into separate files for each year:
The Object User Interface (OUI) is software which provides a framework for coupling environmental-resource models (such as PRMS) with temporal and spatial data sets (Markstrom and Koczot, 2008). Included in OUI is an extended streamflow prediction (ESP) application. For seasonal streamflow forecasting with the PRMS UKB model, OUI can help in two ways. First, it can be used to parse the long historical daily DRAPER climate and streamflow data files into smaller files that have data from individual years in the historical files. The second way OUI can assist with seasonal streamflow forecasting is by determining which 1 year or combination of years from the historical record best represents the climate of the current season.

To first create the separate year climate and streamflow files using OUI:

(1) Start up OUI by clicking on:

. OUI loui.bat

(2) Find and click on:

Model \& Data $>$ PRMS RUNS $>$ ESP node

(3) Right click on: ESP node

(4) Click on Run

(5) Set the forecast start and end dates in the dialog box. For our example we will use a start date of March 1, 2018, and an end date of September 30, 2018.

(6) Click on Run in the dialog box. This action will create PRMS input files for every year in this directory with following names:

. IOUI $\mid$ prms_worklinputlesp $\mid<$ year $>$ ESP_Klam_DRAPER PPT.data

.IOUI $\mid$ prms_work $\backslash$ inputlesp $\mid<$ year $>$ ESP_Klam_DRAPER TMAX.data

.OUI $\mid$ prms_work $\backslash$ inputlesp $\mid<$ year>_ESP_Klam_DRAPER_ TMIN.data

.IOUI/prms_worklinputlesplesp_ESP_<year $>$.data 
It will also run PRMS in the background and create PRMS statvar output files for every year in this directory with following names:

. OUI $\backslash$ prms_work $\backslash$ output $\backslash$ esp $\backslash$ esp_ESP_<year>.statvar

These files contain the simulated flow output for each year. Each file includes two parts. The first part is the same for all the files and includes the period from the starting date of the initialization spin-up ( 3 years before the forecast date) to the date of the forecast. The second part includes simulated flow using climate data from a given historical year. Using our example, a forecast is made on March 1, 2018, for the 7-month period from March 1, 2018, to September 30, 2018. Then, if we use 1984 as an example, the satvar file for that year, 'esp_ESP_1984.statvar', contains simulated flow from March 1, 2015, to February 28, 2018, based on the actual climate for those years. But, for the period March 1, 2018, to September 30, 2018, the file contains simulated streamflow based on climate data from March 1, 1984, to September 30, 1984.
The initialization spin-up period is currently set to 3 years (1,095 days). This can be changed by editing line containing "initLength="1095" in the file:

.IOUI \Klam_basin.xml file

\section{(4) Select appropriate climate year or years:}

After individual simulated streamflow files for individual years have been created, the next step is determining which 1 year, or combination of years, from the historical record is the best representation of the climate of the current season and the forecast period. For example, the forecaster could narrow the selection of years. Criteria like the El Niño Southern Oscillation (ENSO) 3.4 or the Pacific Decadal Oscillation (PDO) can be used to select appropriate years. This last step is done at the discretion of the forecaster. 

Publishing support provided by the U.S. Geological Survey Science Publishing Network, Tacoma Publishing Service Center

For more information concerning the research in this report, contact the Director, Oregon Water Science Center

U.S. Geological Survey

2130 SW 5th Avenue

Portland, Oregon 97201

https://www.usgs.gov/centers/or-water 


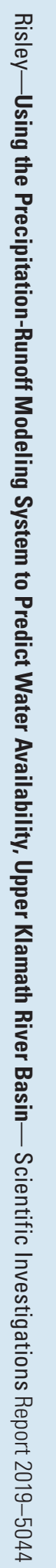

ISSN 2328-0328 (online) 